\title{
EFEITOS DO REIKI SOBRE A VIABILIDADE CELULAR E A ATIVIDADE DA MIELOPEROXIDASE DE NEUTRÓFILOS HUMANOS IN VITRO: ESTUDO EXPERIMENTAL
}

Dissertação apresentada ao Programa de Pósgraduação em Enfermagem na Saúde do Adulto da Escola de Enfermagem da Universidade de São Paulo para obtenção do título de Mestra em Ciências.

Área de concentração:

Enfermagem na Saúde do Adulto.

Orientadora:

Prof. ${ }^{\text {a }}$ Dr. ${ }^{\text {a }}$ Ruth Natalia Teresa Turrini

SÃO PAULO 
AUTORIZO A REPRODUÇÃO E DIVULGAÇÃO TOTAL OU PARCIAL DESTE TRABALHO, POR QUALQUER MEIO CONVENCIONAL OU ELETRÔNICO, PARA FINS DE ESTUDO E PESQUISA, DESDE QUE CITADA A FONTE.

Assinatura:

Data:

Catalogação na Publicação (CIP)

Biblioteca "Wanda de Aguiar Horta"

Escola de Enfermagem da Universidade de São Paulo

\section{Vannucci, Luciana}

Efeitos do Reiki sobre a viabilidade celular e a atividade da mieloperoxidase de neutrófilos humanos in vitro: estudo experimental I Luciana Vannucci. - São Paulo, 2017.

$87 \mathrm{p}$.

Dissertação (Mestrado) - Escola de Enfermagem da Universidade de São Paulo.

Orientadora: Profa. Dra. Ruth Natalia Teresa Turrini

1.Células cultivadas 2.Terapias complementares

3. Neutrófilos 4. Enfermagem. I. Título. 
Vannucci L. Efeitos do Reiki sobre a viabilidade celular e a atividade da mieloperoxidase de neutrófilos humanos in vitro: estudo experimental [dissertação]. São Paulo: Escola de Enfermagem, Universidade de São Paulo; 2017.

\section{ERRATA}

$\begin{array}{cccc}\text { Página } & \text { Linha } & \text { Onde se lê } & \text { Leia-se } \\ 35 & 21 & \text { do toque terapêutico } & \text { da impostação de mãos } \\ 68 & 28 \text { e } 29 & \text { Toque Terapêutico } & \text { impostação de mãos }\end{array}$


Nome: Luciana Vannucci

Título: Efeitos do Reiki sobre a viabilidade celular e a atividade da mieloperoxidase de neutrófilos humanos in vitro: estudo experimental.

Dissertação apresentada ao Programa de Pós-Graduação em Enfermagem na Saúde do Adulto da Escola de Enfermagem da Universidade de São Paulo para obtenção do título de Mestra em Ciências.

Aprovado em:

Banca Examinadora

Orientadora: $\operatorname{Prof}^{\mathrm{a}}$. $\mathrm{Dr}^{\mathrm{a}}$.

Instituição:

Assinatura:

Prof. Dr. Instituição:

Julgamento: Assinatura:

Prof. Dr. Instituição:

Julgamento: Assinatura:

Prof. Dr. Instituição:

Julgamento: Assinatura: 


\section{DEDICATÓRIA}

\section{A Deus pela dádiva da vida!}

Ao meu pai (in memorian) que deixou muita saudade, e a minha mãe que é sabedoria, direção e exemplo de vida para mim.

Ao meu filho, presente da vida, muita gratidão e admiração pelo ser humano íntegro que se tornou. Companheiro em todas as horas.

Ao meu tio Salvador, pelas orientações, por partilhar dos mesmos ideais, e principalmente por ser um exemplo como pessoa e como médico, e à minha tia Alice por ter acompanhado toda minha trajetória de vida.

Enfim, à toda minha família, por buscarmos sempre um caminho para vencermos juntos os períodos difíceis e partilharmos com alegria os momentos de paz.

À Azir Helena Carvalho de Jesus, um exemplo de vida para mim!

À Emília Emi Kawamoto pelo incentivo, pela competência profissional, mas sobretudo pela valiosa amizade!

À Marília Natale Girotto, pelo incentivo e compreensão durante todo o tempo desta pós-graduação. Muito obrigada!

À minha orientadora Prof ${ }^{a} \operatorname{Dr}^{a}$ Ruth Natalia Teresa Turrini pelo direcionamento, incentivo e compreensão nos momentos difíceis. Por acreditar que as Práticas Complementares em Saúde possibilitam novas perspectivas no cuidar!

Aos voluntários que aceitaram participar desta pesquisa, minha eterna gratidão! 


\section{AGRADECIMENTOS}

À minha orientadora Prof ${ }^{a} \mathrm{Dr}^{\mathrm{a}}$ Ruth Natalia Teresa Turrini pela competência, pelas valiosas orientações, pela dedicação e por estar sempre caminhando junto. Gratidão sempre!

À Prof ${ }^{a}$ Dra Rosemari Otton, do Programa de Pós-graduação Interdisciplinar em Ciências da Saúde do Laboratório de Fisiologia Celular e Biologia Molecular da Universidade Cruzeiro do Sul, por ter me introduzido e instruído no campo das pesquisas experimentais, por ter acompanhado cada etapa no laboratório, sempre com determinação, competência e exigência. Muito obrigada!

À $D r^{a}$ Léia Fortes Salles pela importante colaboração durante o Exame de Qualificação $e$, ainda, como pesquisadora, por contribuir sempre para a ampliação do conhecimento das Práticas Complementares em Saúde.

À Profa Dr ${ }^{a}$ Maria Júlia Paes da Silva, que durante muito tempo partilhou, na Escola de Enfermagem da Universidade de São Paulo, toda sua experiência e conhecimento em relação às Práticas Complementares em Saúde.

À Prof ${ }^{\underline{a}} D r^{a}$ Ilda Estefani Ribeiro Marta pelas orientações relevantes dispensadas no Exame de Qualificação, pela disponibilidade e seriedade no trabalho que desenvolve.

Ao Dr. Rafael Queiroz de Souza por ter compartilhado seus valiosos conhecimentos em pesquisas experimentais.

À Universidade Cruzeiro do Sul - Campus Anália Franco pela colaboração na concretização da presente pesquisa desenvolvida no Laboratório de Fisiologia Celular e Biologia Molecular.

Ao doutorando Marcelo Paradiso Marinovic, por ter acompanhado toda esta pesquisa no laboratório, possibilitando que a mesma fosse desenvolvida com seriedade e competência. Muito obrigada!

A todos os pós-graduandos do Laboratório de Fisiologia Celular e Biologia Molecular da Universidade Cruzeiro do Sul, que aprendi a conhecer e admirar, e que contribuíram muito com suas experiências. Obrigada Letícia, Anaysa, Thaís, Fábio, Celso, Maíra, Amaury, enfim, todos vocês, cujo apoio em todas as horas foi fundamental!

A todos os membros do Grupo de Estudos de Práticas Alternativas ou Complementares em Saúde da Escola de Enfermagem da Universidade de São Paulo, muito obrigada por trilharmos os mesmos ideais.

A todos os funcionários da Biblioteca da Escola de Enfermagem da Universidade de São Paulo, pelo atendimento exemplar!

À Juliana Akie Takahashi, por sempre ter compartilhado seu conhecimento, com orientações valiosas. 
A todos os funcionários do Serviço de Pós-graduação da Escola de Enfermagem da Universidade de São Paulo, pela prontidão e orientação em todos os momentos. Muito obrigada!

Ao Bernardo dos Santos, estatístico da Escola de Enfermagem da Universidade de São Paulo, pela competência, disponibilidade e seriedade na análise dos dados.

A todos os funcionários da Escola de Enfermagem da Universidade de São Paulo, agradeço por fazerem parte do meu caminho. 
Se você pensa que pode ou se pensa que não pode, de qualquer forma você está certo. 
VANNUCCI L. Efeitos do Reiki sobre a viabilidade celular e a atividade da mieloperoxidase de neutrófilos humanos in vitro: estudo experimental. [Dissertação de Mestrado] São Paulo: Escola de Enfermagem da Universidade de São Paulo; 2017.

\section{RESUMO}

Introdução: O Reiki está entre as terapias baseadas em energia mais frequentes. Estudar terapias com bases em mecanismos holísticos complexos e dinâmicos, influenciados por diferentes fatores individuais e ambientais exige uma série de avaliações em diferentes modelos experimentais. Neste contexto, o estudo in vitro permite o controle dos fatores externos às células, evita a alta variabilidade individual, propiciando resultados em menor tempo. Dentre os leucócitos, os neutrófilos são aqueles que estão presentes em maior quantidade no sangue periférico, atuando de maneira importante nas fases iniciais das reações inflamatórias, como mecanismo de defesa, estando no rol das primeiras células do sistema imune que se deslocam dos vasos para os tecidos. Objetivo: Avaliar o efeito do Reiki sobre a viabilidade celular e a atividade da enzima mieloperoxidase de neutrófilos humanos in vitro. Método: É um estudo laboratorial, experimental, duplo cego, com abordagem quantitativa. Foi realizado no Laboratório de Fisiologia Celular e Biologia Molecular da Universidade Cruzeiro do Sul - Campus Anália Franco - São Paulo - SP. A amostra de sangue humano foi obtida de cinco voluntários saudáveis. O ensaio necessitou de $20 \mathrm{~mL}$ de sangue obtido por punção venosa periférica. Critério de inclusão: adulto, do sexo masculino, saudável na faixa dos 20 aos 40 anos. Critérios de exclusão: problema de saúde referido, uso de medicamentos, uso de terapia complementar (como terapias energéticas, fitoterapia, meditação e outras). O grupo experimental recebeu aplicação de Reiki, em temperatura ambiente, por meio da imposição de mãos, a $15 \mathrm{~cm}$ de distância por 15 minutos. A aplicação de Reiki foi realizada uma vez ao dia, durante três dias consecutivos, em sessões a cada 24 horas. $O$ grupo controle permaneceu pelo mesmo tempo e nas mesmas condições ambientais do grupo de intervenção, sem a aplicação da técnica de biocampo. As células foram avaliadas pela técnica de exclusão do corante azul de Tripan, que permite diferenciar células vivas e mortas, pela exclusão do corante pelas células viáveis, e contadas em câmara de Neubauer. A atividade da enzima mieloperoxidase (MPO) foi avaliada por meio do ensaio de quimiluminescência. A análise da viabilidade celular foi feita em triplicata utilizando-se como resultado a média. Análise de dados. Medidas de variabilidade e tendência 
central, modelo de equações de estimação generalizadas para distribuição binomial nos dados de viabilidade para comparar os grupos longitudinalmente e um modelo de ANOVA para medidas repetidas não paramétrico para o MPO, ao nível de significância de 5\%. Resultados: As médias da viabilidade celular foram superiores no grupo experimental, quando observadas a média dos cinco ensaios para cada momento de aferição segundo o grupo estudado, com diferença estatisticamente significante $(p=$ 0,0040). A atividade da MPO, expressa em Unidades Relativas de Luminescência foi superior no grupo experimental $(p=0,0020)$. Conclusão: Houve aumento tanto da viabilidade celular, quanto da atividade da enzima mieloperoxidase dos neutrófilos in vitro pertencentes ao grupo experimental quando comparados ao grupo controle.

PALAVRAS-CHAVE: Células Cultivadas. Terapias Complementares. Neutrófilos. Enfermagem. 
VANNUCCI L. Effects of Reiki on cell viability and myeloperoxidase activity of human neutrophils in vitro: experimental study. [disseration] São Paulo: Escola de Enfermagem da Universidade de São Paulo; 2017.

\section{ABSTRACT}

Introduction: Reiki is within as more frequent energy-based therapies. Studying therapies based on complex and dynamic holistic mechanisms, influenced by different individuals and environmental factors, requires a series of assessments in different experimental models. In this context, in vitro studies allow the control of cells external factors, avoiding the high individual variability, providing results in a shorter time. Among leukocytes, neutrophils are those present in greater amounts in the peripheral blood, acting in the main role in the early stages of inflammatory reactions, as a defense mechanism, being in the rank of the first cells of the immune system that move from the vessels to the tissues. Objective: Evaluate the effect of Reiki on cell viability and myeloperoxidase activity of human neutrophils in vitro. Method: It is an experimental, double-blind, laboratory study with a quantitative approach. It was done at Laboratory of Cellular Physiology and Molecular Biology of Cruzeiro do Sul University - Anália Franco Campus - São Paulo - SP. The human blood samples were obtained from five healthy volunteers. The test required $20 \mathrm{~mL}$ of blood obtained by peripheral venous puncture. Inclusion criteria: adult, male, between the ages of 20 and 40 years. Exclusion criteria: volunteers reporting health problems, use of medications and use of complementary therapy (as energy therapies, phytotherapy, meditation and others). The experimental group received the Reiki application, at room temperature, by means of the laying on of hands to $15 \mathrm{~cm}$ of distance by 15 minutes. A Reiki application was performed once a day, for three consecutive days, in sessions every 24 hours. The control group remained at the same period and at the same environmental conditions as the intervention group, but without any application of the biofield technique. The cells were evaluated through the technique of the Trypan blue exclusion test, that allows to differentiate alive and dead cells, through dye exclusion by viable cells, and counted in Neubauer's chamber. The activity of the myeloperoxidase (MPO) enzyme was evaluated by chemiluminescence assay. The analysis of cell viability was done in triplicate using as the result the measures average. Data analysis. Measurements of variability and central tendency, generalized estimation equation model equations for binomial distribution of cell viability data for a 
longitudinal comparison of groups and ANOVA model for non-parametric repeated measures for MPO, at a significance level of $5 \%$. Results: The cellular viability means were higher in the experimental group when evaluated the mean of the five experimental assays in each measurement moment according to the group studied, with a statistically significant difference $(p=0.0040)$. MPO activity, expressed in Relative Luminescence Units, was higher in the experimental group, except in the fifth assay, and with an exacerbation of enzyme activity in the third assay, with a statistically significant difference $(p=0.0020)$. Conclusion: There was an increase in both cell viability and myeloperoxidase enzyme in vitro neutrophils from experimental group when compared to the control group, both with statistically significant differences.

KEYWORDS: Cells, Cultured. Complementary Therapies. Neutrophils. Nursing. 


\section{LISTA DE ILUSTRAÇÕES}

Figura 1 - Esquema de origem das diversas linhagens de células do Sistema Imunológico

Figura 2 - Esquema dos mecanismos utilizados pelos neutrófilos para a morte de patógenos...............................................................

Figura 3 - Representação dos quatro tubos crônicos tipo Falcon (15 mL) após a centrifugação, com o conteúdo sedimentado e o sobrenadante. São Paulo, 2017........................................ 48

Figura 4 - Representação do pellet de neutrófilos São Paulo, 2017 ...... 49

Figura 5 - Quatro das oito placas preparadas para cultivo celular, referentes a um dos grupos. São Paulo, 2017 ....................... 51

Figura 6 - Diagrama do fluxo de cada ensaio. São Paulo, 2017............. 53 


\section{LISTA DE GRÁFICOS}

Gráfico 1 - Representação gráfica da média e erro padrão da viabilidade celular, dada como porcentagem de células vivas, considerando as triplicatas para cada um dos cinco ensaios considerando seus valores para o grupo controle e experimental em relação a cada tempo aferido - $0 \mathrm{~h}, 24 \mathrm{~h}$ e $48 \mathrm{~h}$ do ensaio São Paulo, 2017.

Gráfico 2 - Viabilidade celular média, dada como porcentagem de células vivas, e seu respectivo erro padrão para os grupos controle e experimental para cada tempo aferido - 0h, $24 \mathrm{~h}$ e $48 \mathrm{~h}$. São Paulo, 2017

Gráfico 3 - Atividade da mieloperoxidase, dada em Unidades Relativas de Luminescência (URL), em cada ensaio para os grupos controle e experimental. São Paulo, 2017

Gráfico 4 - Atividade da mieloperoxidase, dada em Unidades Relativas de Luminescência, e seu respectivo erro padrão para os grupos controle e experimental. São Paulo, 2017. 


\section{LISTA DE TABELAS}

Tabela 3.1 - Relação de estudos de práticas complementares de biocampo em modelos in vitro utilizando células humanas... 34

Tabela 5.1 - Média, desvio padrão e erro padrão da viabilidade celular, dada como porcentagem de células vivas, considerando as triplicatas para cada um dos cinco ensaios considerando seus valores para o grupo controle e experimental em relação a cada tempo aferido - 0 h, $24 \mathrm{~h}$ e $48 \mathrm{~h}$ do ensaio. São Paulo, 2017.

Tabela 5.2 - Descrição da viabilidade celular média, dada porcentagem de células vivas, nos grupos controle e experimental conforme a aferição em cada momento diferente do tempo - Oh, 24h e 48h do ensaio. São Paulo, 2017.

Tabela 5.3 - Descrição da atividade da mieloperoxidase, dada como Unidades Relativas de Luminescência (URL), nos grupos controle e experimental. São Paulo, 2017. 


\section{LISTA DE SIGLAS}

CDC

ECG

EEG

EMG

ERO

ESAS

EUA

FATC-F

FATC-G

G-CSF

GEE

ICAM

LAK

MPO

NCCAM

$\mathrm{NCClH}$

NET

$\mathrm{NIH}$

NK

NO

PBS

PCNA

PIC

PNPIC
Center for Diseases Control

Eletrocardiografia

Eletroencefalografia

Eletromiografia

Espécie reativa de oxigênio

Edmonton Symptom Assessment System

Estados Unidos da América

Functional Assesment of Cancer Therapy Fadigue subscale Functional Assessment of Cancer Therapy, General Version Fator estimulador de colônias de granulócitos

Modelo de equações de estimação generalizadas

Intercellular Adhesion Molecule

Lymphokine Activated Killer

Mieloperoxidase

National Center for Complementary and Alternative Medicine National Center for Complementary and Integrative Health Neutrophil Extracelular Traps

National Institute of Health

Natural Killer

Óxido Nítrico

Tampão Fosfato Salino

Marcação Nuclear de Células em Proliferação

Práticas Integrativas e Complementares

Política Nacional de Práticas Integrativas e Complementares 
SUS

Sistema Único de Saúde

TCLE

Termo de Consentimento Livre e Esclarecido

TLR

Toll-like receptors

USP

Universidade de São Paulo

VAS

Escala análoga visual 


\section{LISTA DE SÍMBOLOS}

$\begin{array}{ll}\text { A } & \text { Ampére } \\ { }^{\circ} \mathrm{C} & \text { Graus Celsius } \\ \mathrm{g} & \text { Força gravitacional } \\ \mathrm{h} & \text { Horas } \\ \mathrm{Hz} & \text { Hertz } \\ \mathrm{min} & \text { Minutos } \\ \mathrm{mL} & \text { Mililitros } \\ \mathrm{mm} & \text { Milímetros } \\ \mathrm{mM} & \text { Milimol } \\ \mathrm{ng} & \text { Nanograma } \\ \mathrm{URL} & \text { Unidade Relativa de Luminescência } \\ \mathrm{V} & \text { Volts } \\ \mathrm{W} & \text { Watts } \\ \mu \mathrm{L} & \text { Microlitro } \\ \end{array}$




\section{SUMÁRIO}

1 INTRODUÇÃO

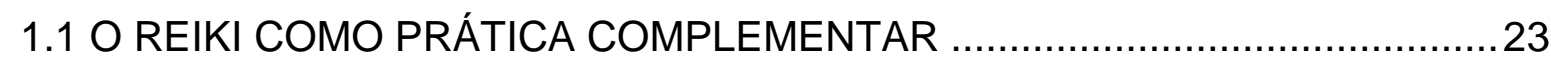

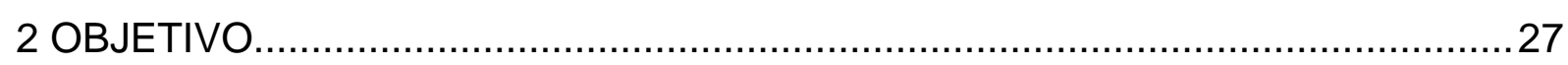

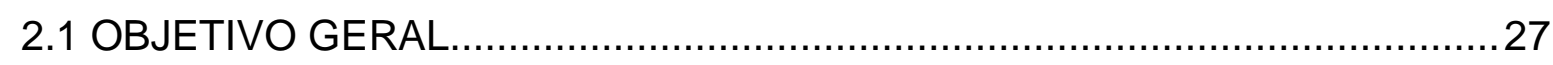

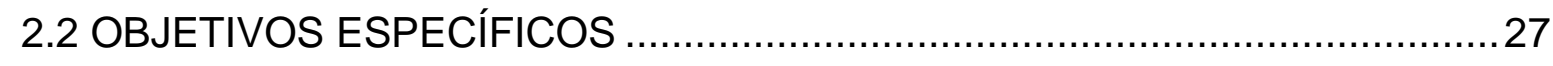

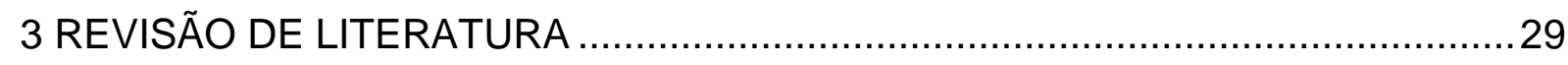

3.1 AVALIAÇÃO DO REIKI E OUTRAS TÉCNICAS ENERGÉTICAS IN VITRO.. 31

3.2 PRÁTICAS COMPLEMENTARES E SISTEMA IMUNE ...................................35

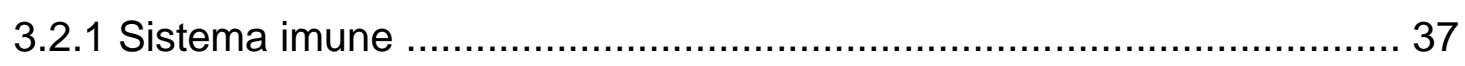

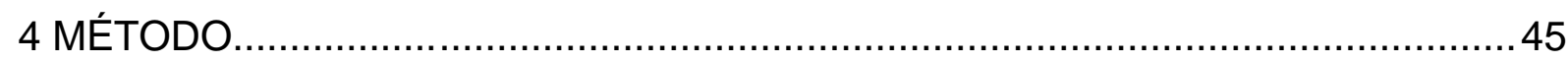

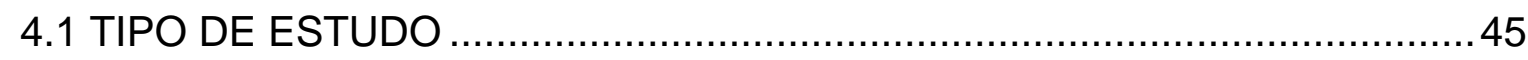

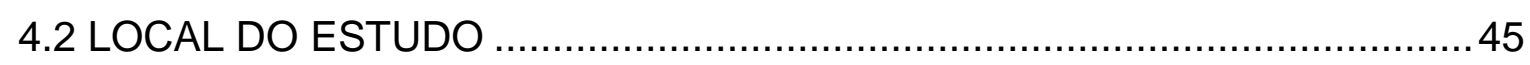

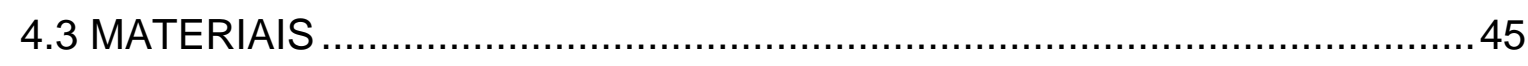

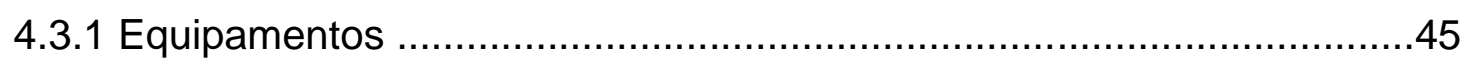

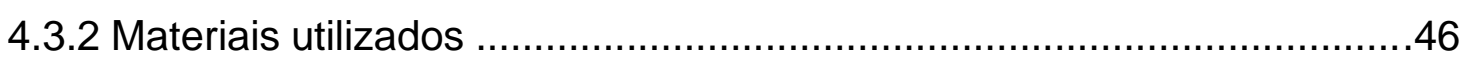

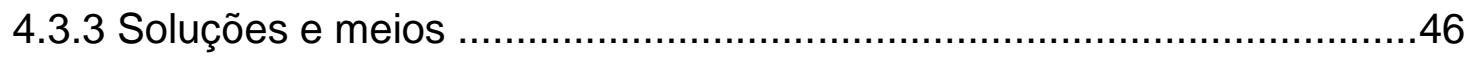

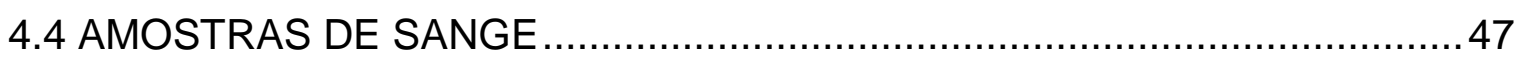

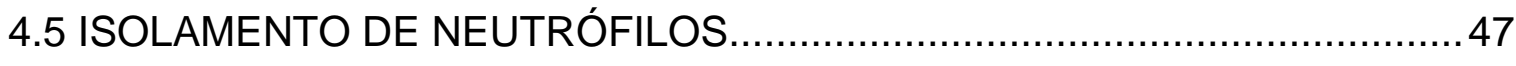

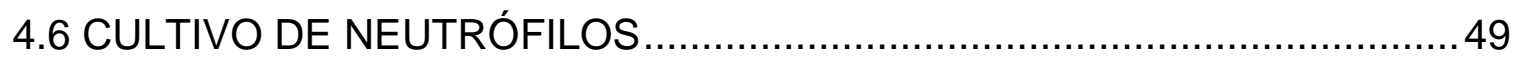

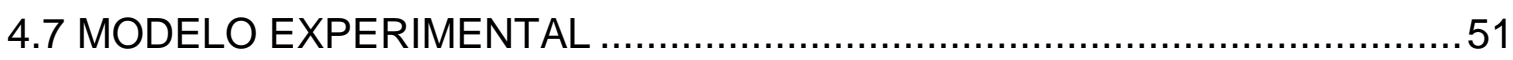

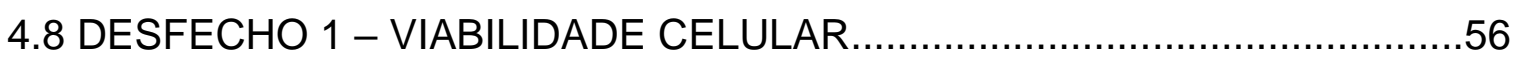

4.9 DESFECHO 2 - DOSAGEM DA ENZIMA MIELOPEROXIDASE.................56

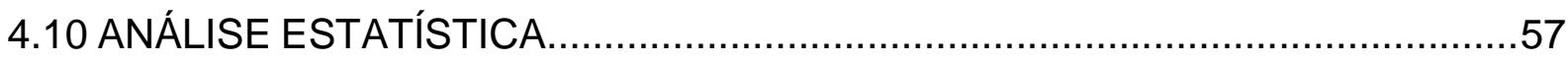

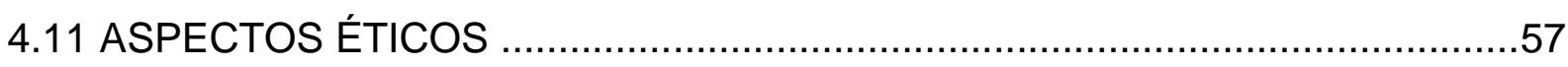

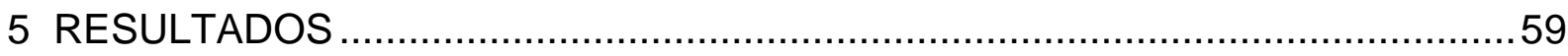

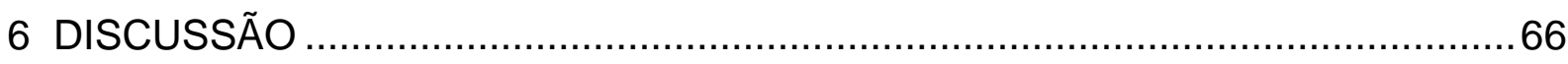

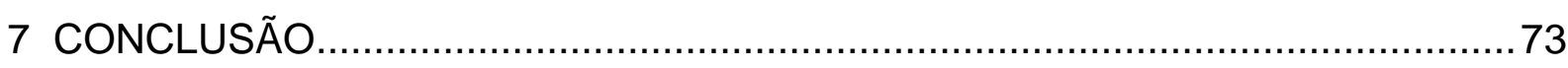

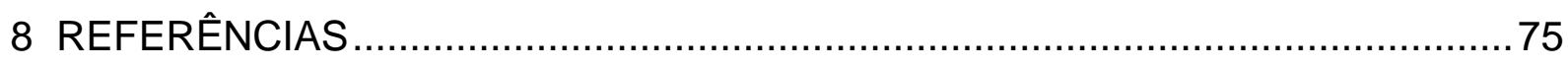

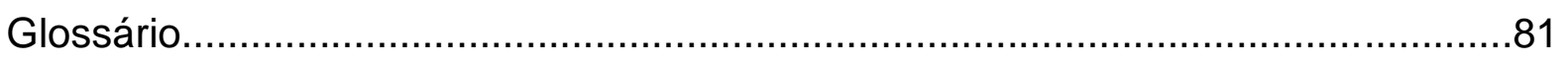

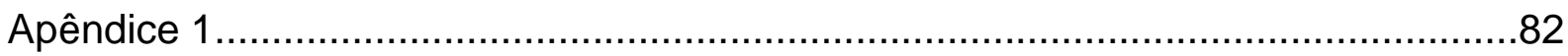

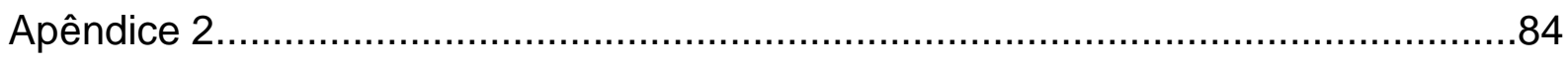

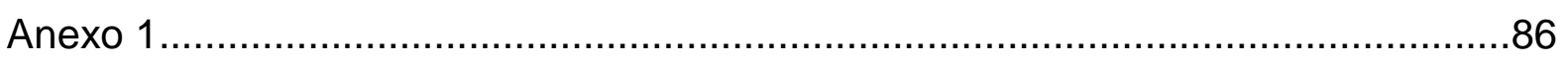

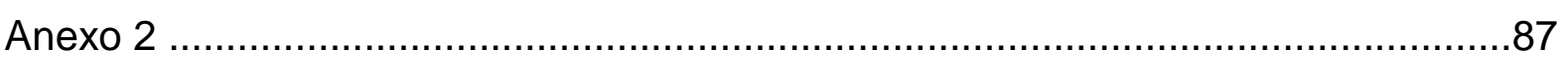


1 INTRODUÇÃO 


\section{INTRODUÇÃO}

No Brasil, as práticas integrativas e complementares foram integradas ao Sistema Único de Saúde (SUS) no ano de 2006 pela Política Nacional de Práticas Integrativas e Complementares (PNPIC) (Sousa et al., 2012), com foco no nível primário de atenção à saúde. Segundo o Ministério da Saúde, em 2008, havia no país cerca de 800 municípios realizando essas atividades (Sousa et al., 2012). Embora tenham sido incorporadas apenas recentemente pelo governo brasileiro, essas práticas, muitas delas milenares, começaram a ser, de fato, aceitas a partir da década de $60 \mathrm{com}$ a revolução cultural e começaram a ter ampla aceitação por profissionais da saúde e pelo público leigo nos últimos 30 anos (Salles e Silva, 2011) (Anexo 1).

O Reiki, a prática complementar objeto do presente estudo, não fazia parte das práticas elencadas na PNPIC de 2006. Porém, no dia 13 de janeiro de 2017, por meio de uma Portaria do Ministério da Saúde publicada no Diário Oficial da União, o Reiki foi incluído como uma prática integrativa na "Tabela de Procedimentos" oferecidos pelo Sistema Único de Saúde (SUS), na categoria de "ações de promoção e prevenção em saúde". A Portaria n 849, de 27 de março 2017 inclui também a Arteterapia, Ayurveda, Biodança, Dança Circular, Meditação, Musicoterapia, Naturopatia, Osteopatia, Quiropraxia, Reflexoterapia, Shantala, Terapia Comunitária Integrativa e Yoga à Política Nacional de Práticas Integrativas e Complementares (Anexo 2).

O Reiki é uma técnica oriunda de antigas práticas tibetanas, entretanto, suas bases modernas foram criadas no Japão, no século XX, por Mikao Usui (1865-1926). Sua difusão é marcada pelo trabalho de Chujiro Hayashi (1878-1940), que distanciou a técnica de rituais religiosos, e Hawayo Takata (1900-1980), responsável em difundir a prática nos Estados Unidos da América (EUA) (Miles e True, 2003). Reiki vem da composição das palavras Rei, que significa energia universal, e ki, a energia sutil (similar ao chi chinês) (Miles e True, 2003).

O Reiki não se associa a um sistema filosófico ou religioso, assim como a crença na técnica é desnecessária para que os efeitos do Reiki ocorram (De’ Carli, 2001). 
Pela técnica Reiki, a energia vital é canalizada para o terapeuta, por meio de sons e símbolos sagrados (Motta, 2014). Tradicionalmente o Reiki atua por meio da passagem da energia vital através do praticante, como uma via da energia universal, para equilíbrio e fortalecimento da energia do paciente (Miles e True, 2003).

A formação nesta técnica é realizada por um mestre habilitado, por meio de um processo, que recebeu várias denominações, como "iniciação", "ajustamento" e, atualmente, "sintonização" ou "harmonização". Tal processo permite reativar no aluno os canais de captação e distribuição de energia do corpo, restabelecendo o modo primordial, propiciando harmonização e equilíbrio tanto ao aplicador, quanto para quem recebe o Reiki (Salles e Silva, 2011). A energia dispensada por quem aplica o Reiki, flui de acordo com a necessidade do receptor. Assim, o local sob a aplicação do Reiki receberá energia até atingir seu equilíbrio (De' Carli, 2001).

Os níveis de formação do praticante de Reiki podem ser diferentes. Na escola Usui, a original, a formação do terapeuta consiste em três níveis, sendo a prática do auto tratamento recomendável em todos eles (Miles e True, 2003). Nesta escola, o nível I ou físico, denominado "O Despertar", possibilita que o corpo físico do praticante fique receptivo à energia vital universal que canalizará através do chacra ${ }^{1}$ da coroa, tornando-se capaz de distribuí-la diretamente em si mesmo ou transferi-la para outro ser vivo por meio de toques sutis ou imposição das mãos. No nível II ou mental, chamado de "Transformação", o praticante atuará em circunstâncias emocionais e mentais. Nesta etapa, o praticante é sintonizado e instruído a utilizar os três símbolos sagrados do Reiki, com os respectivos mantras. Ainda há o nível III que se apresenta subdividido em nível III-A e nível III-B. No nível III-A denominado "Consciência", o praticante é graduado como mestre interior, o que é alcançado mediante o recebimento do símbolo de mestre. Este nível permite, ao praticante, lidar com uma quantidade maior de energia, equilibrando diversas pessoas simultaneamente. Tal fato é atribuído à capacidade de potencialização desse símbolo sobre os efeitos proporcionados pelos símbolos anteriormente recebidos. O nível III-B, descrito como "Mestrado", permite que o praticante ensine o Reiki. Implica, também, em um estudo meticuloso da técnica de Reiki, por parte do praticante (Salles e Silva, 2011).

\footnotetext{
${ }^{1}$ Segundo De'Carli (2001), chacra significa "roda" em sânscrito. Os chacras são considerados no Oriente como cones de energia que giram e que se localizam nos canais energéticos (meridianos).
} 
Mikao Usui, ainda, destacava para seus alunos a relevância de se manter um comportamento mental pacífico, oferecendo a estes os seguintes preceitos: "Só por hoje, não sinta raiva; só por hoje, não se preocupe; seja humilde; seja honesto em seu trabalho; tenha compaixão por si mesmo e pelos outros" (Miles e True, 2003).

Variações na técnica de aplicação do Reiki, em termos de sequência, surgiram em razão de sua difusão pelo ocidente (Motta, 2014; Salles e Silva, 2011), mas este estudo se aterá à técnica da escola tradicional Usui.

A prática do Reiki se dá pelo toque suave em 12 pontos específicos da cabeça e do dorso, podendo ser aplicado também diretamente no local de alguma lesão. Preferencialmente, é realizado em um ambiente relaxante onde o paciente está deitado ou sentado, mas o toque efetivo não é necessário e, muitas vezes, pode ser realizado à distância. Tradicionalmente o Reiki atua por meio da passagem da energia vital através do praticante, como uma via da energia universal, para equilíbrio e fortalecimento da energia do paciente (Miles e True, 2003).

O Reiki tem sido estudado, principalmente, nos seguintes escopos: (1) estresse/relaxamento: redução da frequência cardíaca, da pressão sanguínea; (2) cura de feridas: melhora do sistema imune; (3) dor: produção de endorfinas; (4) mudança de correlações biológicas: atuação no sistema nervoso autonômico, favorecendo o parassimpático em relação ao simpático (Miles e True, 2003; Rindfleisch, 2010) .

Comumente considera-se o Reiki uma terapia de biocampo de baixo risco, entretanto, algumas ressalvas devem ser consideradas em casos de psicoses e em pacientes que não podem ter súbitos momentos de emoções fortes, porque estes podem acontecer durante as aplicações. Esta terapia também não deve ser utilizada como substituta à medicina convencional em casos onde há técnicas comprovadamente mais eficazes como tratamento de base, como no caso de infecções agudas (Rindfleisch, 2010). 


\subsection{O REIKI COMO PRÁTICA COMPLEMENTAR}

Estima-se que $40 \%$ dos americanos utilizam algum tipo de prática complementar, sendo pelo menos $13 \%$ orações e práticas espirituais e $1,0 \%$ terapias baseadas em energia (Lucchetti et al., 2013). Uma pesquisa do National Health Information Survey mostra que $0,5 \%$ dos americanos, em 2007, usaram alguma forma de medicina baseada em energia. Um estudo similar, pelo Center for Diseases Control (CDC), em 2004, indicou que 0,5\% dos cidadãos americanos praticavam Qi gong e 1,0\% utilizavam Reiki, sendo esta uma das técnicas de biocampo mais populares nos EUA (Rindfleisch, 2010). Nos EUA, mais de 50 hospitais e clínicas oferecem, de alguma forma, medicina baseada em energia aos seus pacientes (Rindfleisch, 2010), sendo a maioria utilizada de forma complementar ao tratamento convencional (Warber et al., 2004)

Em 1998, foi fundado pelo National Institute of Health $(\mathrm{NIH})$ o National Center for Complementary and Integrative Health $(\mathrm{NCClH})$ - formalmente conhecido como National Center for Complementary and Alternative Medicine (NCCAM), que tem como missão definir, por meio de pesquisas científicas rigorosas, a aplicabilidade e a segurança das intervenções integrativas e complementares em saúde, e seu papel na promoção e cuidado da saúde (NCCIH, 2015).

A classificação das práticas integrativas e complementares (PIC) proposta pelo $\mathrm{NCClH}$ abrange cinco diferentes categorias: (1) terapias mente-corpo, que são técnicas que trabalham mente/corpo, como relaxamento profundo, práticas respiratórias, meditação, bioeedback, ioga, musicoterapia, oração, tai chi, Qi gong, arteterapia, entre outras; (2) terapias com base biológica, que atuam com substâncias encontradas na natureza, como óleos vegetais (aromaterapia), ervas (fitoterapia), dietoterapia, entre outras; (3) terapias corporais para o tratamento físico, tais como massoterapia, terapia craniosacral, quiropraxia, entre outras; (4) terapias vibracionais, que trabalham com saúde vibracional e energética, como Reiki, toque terapêutico, healing touch, entre outras; e (5) os sistemas medicinais da Medicina Tradicional Chinesa e a Medicina Ayurvédica (NCCIH, 2015). 
A emergente popularidade das técnicas de cura por meio da energia, permite esforços conjuntos para a detecção e mensuração do campo energético humano conhecido como biocampo (Forbes et al., 2004).

O biocampo é citado de forma tradicional em muitas culturas, como o prana para os Hindus, o Qi (chi) para os chineses, o ki para os japoneses, e também aparece em elementos como nos três doshas da medicina Ayruvédica e nos quatro humores de Galeno. Muitas práticas médicas propõem a cura por meio dessas energias, como a acupuntura, acupressão, toque terapêutico, Qi gong, Johrei, Reiki, dentre outros (Rosch, 2009).

O conceito foca-se no fato que, da mesma forma que o corpo humano está em constante circulação de matéria, como observado no fluxo sanguíneo, ele também possui uma constante circulação elétrica de íons, moléculas, células e tecidos, como no caso da energia elétrica - e, como consequência, magnética (Movaffaghi e Farsi, 2009).

As práticas de biocampo, como o Reiki, possuem referências consistentes com teorias de física, física quântica e teoria da supercorda ${ }^{2}$, podendo um campo bioeletromagnético interferir na saúde, principalmente em relação ao potencial redox e em reações de hidrolização (Miles e True, 2003).

O biocampo é definido como um campo eletromagnético complexo, dinâmico e endógeno resultante da superposição de campos eletromagnéticos do organismo de acordo com os princípios da física convencional. Considera-se, entretanto, que há outros tipos de energia no biocampo, além da eletromagnética (Forbes et al., 2004), o que dificulta sua compreensão pela medicina ocidental e coloca em dúvida práticas tradicionais como o Reiki. Este biocampo, também, seria capaz de sofrer o efeito da intencionalidade, permitindo praticantes influírem e modificarem o biocampo do paciente através da intenção de cura (Rosch, 2009).

Os componentes bioeletromagnéticos individuais podem ser aferidos por técnicas como a eletrocardiografia (ECG), eletroencefalografia (EEG), eletromiografia (EMG) e

\footnotetext{
a Segundo Abdalla (2005), a teoria da supercorda surgiu na tentativa de explicar as leis da teoria de interações nucleares fortes. Essa teoria, simplificadamente, deriva-se de um simples conceito: todas as partículas essenciais da natureza não são objetos pontuais, mas parte de pequenas cordas que vibram no espaço-tempo (Abdalla, 2005).
} 
a ressonância magnética. Observa-se, por ECG e EEG, que os padrões eletromagnéticos são alterados com a aproximação de duas pessoas (Rindfleisch, 2010).

A detecção do biocampo por meio da eletromiografia de superfície - técnica adaptada onde os eletrodos são colocados em pontos tradicionais da cura energética (como os chacras) com aferição sem os filtros tradicionais (que permitem a distinção apenas dos pulsos elétricos musculares) - mostrou que durante a aplicação de toque terapêutico em um paciente, havia tanto aumento na frequência (acima de $20 \mathrm{~Hz}$ ) quanto na intensidade (acima de $10 \mathrm{~dB}$ ) bioeletromagnéticas, sendo estas reduzidas, gradativamente, após a intervenção (Forbes et al., 2004).

Em um estudo no Havaí avaliou-se o perfil da ressonância magnética de um grupo de pacientes que receberam, de forma randomizada, cega e à distância, a intervenção vibracional realizada por praticantes de diversas técnicas de medicina complementar. Observou-se que os resultados do perfil da área do córtex cerebral dos grupos foram estatisticamente diferentes (Achterberg et al., 2005; Rindfleisch, 2010).

Estudar entidades e mecanismos holísticos complexos e dinâmicos, como o biocampo e as PICs de enfoque energético, influenciados por diferentes fatores individuais e ambientais, exige uma série de avaliações em diferentes modelos experimentais. Neste contexto, o estudo in vitro permite o controle dos fatores externos às células, evita a alta variabilidade individual, permite resultados em menor tempo e pode ser facilmente reproduzido. Neste estudo, optou-se por utilizar os neutrófilos, que são células envolvidas no processo de imunidade inata, pelo seu potencial quantitativo de presença na circulação sanguínea. Ensaios clínicos têm demonstrado melhoria no sistema imunológico, em especial no que tange à cura de feridas (Rindfleisch, 2010), em pacientes que foram submetidos a sessões de Reiki. 
2 OBJETIVOS 


\section{OBJETIVOS}

\subsection{OBJETIVO GERAL}

Avaliar o efeito da aplicação de Reiki sobre a viabilidade celular e sobre a atividade da enzima mieloperoxidase de neutrófilos in vitro, obtidos a partir de amostras de sangue humano.

\subsection{OBJETIVOS ESPECÍFICOS}

- Avaliar o efeito da aplicação de Reiki sobre a viabilidade dos neutrófilos cultivados até 48 horas.

- Avaliar o efeito da aplicação do Reiki sobre a atividade da enzima mieloperoxidase dos neutrófilos. 
3 REVISÃO DE LITERATURA 


\section{REVISÃO DE LITERATURA}

Crawford et al. (2006) avaliaram os resultados do Reiki sobre o comportamento, memória e disfunção cognitiva em pacientes com doença de Alzheimer. Neste estudo, 24 pacientes com disfunção cognitiva foram randomicamente divididos em grupos controle e experimental, sendo cada um composto por 12 pacientes com níveis estatisticamente iguais de estado mental. Os pacientes do grupo experimental receberam sessões semanais de Reiki de 30 minutos, durante um mês e o outro grupo não recebeu tratamento de nenhum tipo. Houve melhoria significativa na memória e na disfunção comportamental $(p<0,05)$, assim como no estado mental de forma geral $(p=0,005)$.

Tsang, Carlson e Olson (2007) estudaram os efeitos do Reiki sobre a fadiga, dor, ansiedade e qualidade de vida, em pacientes com câncer que tivessem recentemente completado a quimioterapia e que possuíssem escore de fadiga superior a três pelo ESAS (Edmonton Symptom Assessment System). Neste estudo piloto cruzado, indivíduos passaram por sessões de Reiki (intervenção), de aproximadamente 45 minutos, por cinco dias consecutivos e por um período de descanso (controle) de mesma duração. Dividiram, aleatoriamente, os indivíduos naqueles que receberam as sessões de Reiki antes dos períodos de descanso e aqueles que receberam a intervenção após o descanso. Os pacientes foram avaliados conforme nos escores FATC-F (Functional Assesment of Cancer Therapy Fadigue subscale), indicador do estado de fadiga, dor e ansiedade, e FATC-G (Functional Assessment of Cancer Therapy, General Version), indicador de qualidade de vida. Observaram que o Reiki foi capaz de reduzir os níveis de fadiga, dor e cansaço, entretanto estatisticamente essa redução não foi diferente da obtida pelo grupo controle. Na qualidade de vida, houve uma melhoria significante pelo Reiki e esta foi estatisticamente maior do que a obtida no grupo controle.

Assefi et al. (2008), em estudo clínico randomizado, duplo cego, avaliaram o efeito do Reiki sobre a fibromialgia. Foram selecionados 100 voluntários, dos quais sete desistiram antes de receberam a terapia e 12 desistiram após receberam de uma a oito sessões de Reiki. Os voluntários foram randomicamente divididos em quatro grupos, Reiki direto, Reiki à distância, Reiki placebo direto e Reiki placebo à distância. 
Não houve diferença estatisticamente significante entre os grupos controle e experimental para os escores da escala análoga visual (VAS) para aferição de dor, fadiga, qualidade do sono e bem-estar geral, quanto para o funcionamento mental e físico avaliado pela Medical Outcomes Study 36-item Short-Form Health Survey .

Díaz-Rodriguez et al. (2011), em um estudo randomizado, placebo controlado, duplo-cego, com desenho cruzado, verificaram os efeitos do Reiki sobre profissionais com síndrome de burnout, comparados ao grupo placebo, com relação a temperatura corporal, níveis de cortisol e variabilidade da frequência cardíaca. Foram alocadas, randomicamente, 21 voluntárias entre o grupo de intervenção, que recebeu aplicação de Reiki por 30 minutos, e o grupo que recebeu o Reiki placebo, aplicado por pessoa sem conhecimento da técnica. Os autores observaram que no grupo que recebeu a intervenção do Reiki, houve alterações estatisticamente significantes nos padrões do ECG (eletrocardiograma) e na elevação na temperatura corpórea, demonstrando estímulo do sistema nervoso parassimpático. Os autores não encontraram, entretanto, diferença significativa no fluxo salivar e nos níveis de cortisol salivar .

Salles et al. (2014), em estudo clínico randomizado, transversal, descritivo e duplo cego, avaliaram o efeito imediato do Reiki sobre a pressão arterial em 66 portadores de hipertensão arterial. Todos os pacientes do grupo de intervenção receberam a aplicação de Reiki por 20 minutos, sendo a pressão arterial aferida antes e após cada sessão. O grupo controle permaneceu em repouso durante o mesmo período e o grupo placebo recebeu uma imitação de Reiki. Nesse ensaio, observaram a redução estatisticamente significativa na pressão arterial nos três grupos, entretanto, no grupo de intervenção foi estatisticamente mais acentuada que nos demais .

Midilli e Eser (2015), avaliaram os efeitos do Reiki na dor, ansiedade e nos parâmetros hemodinâmicos no pós-operatório de cesarianas. Foram selecionadas 100 pacientes, randomicamente separadas no grupo controle e intervenção, havendo perda de cinco pacientes de cada grupo durante o experimento. O Reiki foi aplicado em duas sessões de 30 minutos, sendo uma nas primeiras $24 \mathrm{~h}$ e outra nas $48 \mathrm{~h}$ do pós-cirúrgico. O grupo controle passou pelos mesmos procedimentos e pelo mesmo tempo do que o grupo de intervenção, mas ao invés de receberem o Reiki, ficaram deitados em uma cama por 30 minutos. Os autores observaram uma redução estatisticamente significante na necessidade de analgésicos, na frequência 
respiratória, nos níveis de dor e de ansiedade no grupo que recebeu Reiki, porém, não houve alteração quanto aos outros parâmetros avaliados .

\subsection{AVALIAÇÃO DO REIKI E OUTRAS TÉCNICAS ENERGÉTICAS IN VITRO}

Modelos in vitro, embora amplamente utilizados como modelos em processos fisiológicos, patológicos e no desenvolvimento de novos fármacos, são pouco difundidos no estudo do biocampo, de acordo com os poucos estudos encontrados na literatura. Os resultados das pesquisas são contraditórios, enquanto alguns observam diferenças significativas para diversos parâmetros, como proliferação e viabilidade celular (Gronowicz, 2011; Gronowicz et al., 2008; Lucchetti et al., 2013; Rubik et al., 2006; Shah et al., 1999; Shao et al., 2009), outros não observam significância (Hall et al., 2007; Mager et al., 2007; Taft et al., 2005, 2003, Yount et al., 2013, 2004). De fato, há uma grande variação de modelos e desenhos experimentais, o que inclui a linhagem celular utilizada, a técnica tradicional escolhida para intervenção, e o método de análise dos resultados.

Ao mesmo tempo, alguns estudos, embora poucos, conseguem avaliar in vitro o mecanismo de ação da prática energética, aproximando os tratamentos complementares ao entendimento da medicina convencional Kiang et al. (2005), por exemplo, observaram em seus estudos que a aplicação de técnicas de biocampo são capazes de aumentar a concentração intracelular de cálcio por mediarem a troca de $\mathrm{Na}^{+} / \mathrm{Ca}^{+}$com a abertura dos canais de cálcio voltagem-dependentes do tipo $L^{\text {b3 }}$.

Em 2008, demonstrou-se que o toque terapêutico, sob dois tratamentos de dez minutos por semana ao longo duas semanas, estimulou a proliferação de osteoblastos, tenócitos e fibroblastos em relação aos grupos placebo ("sham") e controle. Neste estudo, as células foram contadas por meio da marcação por [3H]-

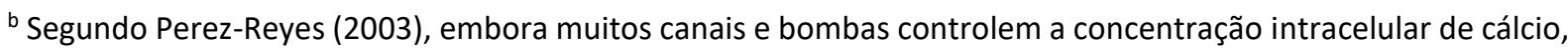
os voltagem-dependentes possuem importante papel nesse controle porque, além de atuarem como segundos mensageiros, os íons de cálcio também podem despolarizar a membrana e assim ativar esses canais dependentes da voltagem(Perez-Reyes, 2003). Eles estão presentes em muitos processos fisiológicos, mas podemos citar, por exemplo, a excitabilidade de neurônios sensoriais, muito importante nos estudos de analgesia (Carvalho e Lemônica, 1998).
} 
timidina quanto por marcação nuclear de células em proliferação (PCNA), e observouse, também, aumento na matriz óssea e na mineralização ${ }^{15}$. Este mesmo grupo, em 2011, avaliando duas linhagens de osteossarcoma humano, Saos-2 e HOS, observou inibição da proliferação neoplásica em HOS, e diminuição na mineralização de ambas as linhagens, em comparação aos grupos controle e placebo (Gronowicz, 2011).

Em outro estudo demonstrou-se que a aplicação de transferência de energia por um praticante de Yuanji, inibia a proliferação de células cancerígenas humanas (MCF7, K562, MEL6 e LNCaP) (Shah et al., 1999). Os pesquisadores deste ensaio, entretanto, selecionaram o praticante da técnica por uma análise prévia junto a outros três indivíduos (que realizavam toque terapêutico e cura energética) por meio da capacidade deles em reduzir em 15\% a contagem celular em pelo menos duas de três aplicações. O autor concluiu que essa pré-seleção induziu resultados mais favoráveis ao ensaio do que os citados em outros artigos (Shah et al., 1999).

A utilização do Johrei em linhagem glial humana mista primária, entretanto, não obteve resultados significativos. Nesse ensaio, as células foram irradiadas com raio$X$, o que inibe sua proliferação por dano direto ao DNA. A intervenção foi realizada por uma aplicação de 30 minutos, a $20 \mathrm{~cm}$ da cultura. As células foram acompanhadas a cada meia-hora quanto à proliferação e à viabilidade até um total de 22,5h, mas não foi observado aumento na proliferação ou viabilidade celular22. Outros dois estudos in vitro, do mesmo grupo de pesquisa, com a aplicação de Johrei sobre células da linhagem SF188 GM (glioblastoma multiforme humano) não observaram diferenças quanto às taxas de proliferação e morte celular entre o grupo que recebeu a aplicação e o grupo controle (Taft et al., 2005, 2003).

Em um tratamento de biocampo (técnica não discriminada), Yount et al (2013), avaliaram o efeito da dose (número e tempo das sessões) e da distância entre o praticante e o objeto da intervenção com o objetivo de verificar a redução na viabilidade de células cancerígenas. Os pesquisadores realizaram a intervenção sobre a linhagem U87 de glioblastoma, e observaram em triplicata que sobre uma análise de regressão logística, tanto na avaliação da distância de aplicação $(0,25 \mathrm{~m}, 3 \mathrm{~m}$ e $2.000 \mathrm{~m})$, quanto no número de sessões (1,2 ou 5) ou tempo de duração de cada sessão (5min, 10min e 25min) não houve diferença estatística nos resultados. Yount et al., em 2007, demonstraram que astrócitos humanos submetidos a estresse oxidativo (por peróxido de oxigênio), que receberam tratamento por praticantes de Qi 
gong, de Johrei e por indivíduos com habilidades inatas, não apresentaram diferenças estatísticas quanto a taxa de mortalidade celular em relação ao grupo controle (Mager et al., 2007). Ao inverter o propósito metodológico, avaliando-se a capacidade do praticante em distinguir em quais frascos haveria alterações patológicas (células cancerígenas ao invés de meio de cultura ou água estéril) não se observou diferenças estatisticamente significantes em relação ao grupo controle (Yount et al., 2004).

Estudos avaliando o efeito das práticas complementares em culturas bacterianas são incomuns. Em 2006, um estudo demonstrou que não havia diferença estatisticamente significativa na contagem de colônias de Escherichia coli, após choque térmico, entre as placas tratadas em uma sessão de 15 minutos com Reiki daquelas do grupo controle. Entretanto, havia estatisticamente maior número de colônias no grupo tratado com Reiki, caso o praticante houvesse, anteriormente, feito alguma sessão em um paciente $(p<0,05)$, uma vez que estivesse em boa condição de bem-estar social $(p<0,031)$, físico $(p<0,030)$ e emocional $(p=0,026)$ (Rubik et al., 2006).

Em 2009, um estudo da prática de Qi gong avaliou o efeito da intenção do praticante sobre o crescimento de culturas de Escherichia coli. Os pesquisadores dividiram 75 culturas entre um grupo que recebeu a intervenção com a intenção de proliferação, outro com inibição, além do grupo controle que não recebeu qualquer tipo de intervenção. Foi observada maior densidade de colônias na intervenção com intenção de crescimento em relação ao controle $(p<0,05)$ e menor densidade das colônias que sofreram intervenção com intenção de inibição, em relação ao grupo controle $(p<0,01)$ (Shao et al., 2009). Em 2013, pesquisa realizada no Laboratório de Microbiologia da Santa Casa de Misericórdia de São Paulo, demonstrou o efeito da intenção sobre o crescimento de uma cultura de Escherichia coli utilizando como forma de intervenção o passe espírita (definido pelos autores como a transfusão de energia que muda o biocampo celular). Observou-se diferença significativa na inibição do crescimento bacteriano entre os grupos que receberam o passe, em relação ao grupo controle, não havendo variação em relação à intenção (inibição ou proliferação) do praticante (Lucchetti et al., 2013).

Elaborou-se uma tabela para sintetizar os estudos sobre Reiki e outras terapias de biocampo em células humanas (Tabela 3.1). 
Tabela 3.1 - Relação de estudos de práticas complementares de biocampo em modelos in vitro utilizando células humanas.

\begin{tabular}{|c|c|c|c|}
\hline Trabalho & Técnica & Linhagens & Descrição \\
\hline $\begin{array}{l}\text { Shah et al., } \\
1999\end{array}$ & Yuanji & $\begin{array}{l}\text { Células MCF-7 (câncer de } \\
\text { mama ER+), K562 } \\
\text { (leucemia), MEL6 } \\
\text { (melanoma com knockout } \\
\text { para p53) e LNCaP } \\
\text { (câncer de próstata). }\end{array}$ & $\begin{array}{c}\text { Inibição da } \\
\text { proliferação celular }\end{array}$ \\
\hline $\begin{array}{l}\text { Yount et al., } \\
2004\end{array}$ & $\begin{array}{c}\text { Não } \\
\text { discriminada }\end{array}$ & $\begin{array}{l}\text { Células cancerígenas; } \\
\text { meio de cultura; água } \\
\text { estéril }\end{array}$ & $\begin{array}{l}\text { Praticantes não } \\
\text { conseguiram } \\
\text { distinguir pelo } \\
\text { biocampo qual era o } \\
\text { frasco com células } \\
\text { cancerígenas }\end{array}$ \\
\hline $\begin{array}{l}\text { Kiang et al., } \\
2005\end{array}$ & $\begin{array}{c}\text { Não } \\
\text { discriminada }\end{array}$ & $\begin{array}{l}\text { Linfócitos T Jurkat } \\
\text { humanos }\end{array}$ & $\begin{array}{l}\text { Aumento da } \\
\text { concentração de } \\
\text { cálcio intracelular }\end{array}$ \\
\hline $\begin{array}{l}\text { Taft et al., } \\
2003\end{array}$ & Johrei & $\begin{array}{l}\text { SF188 GM (glioblastoma } \\
\text { multiforme humano) }\end{array}$ & $\begin{array}{l}\text { Não há diferença } \\
\text { quanto proliferação e } \\
\text { mortalidade em } \\
\text { relação ao grupo } \\
\text { controle }\end{array}$ \\
\hline $\begin{array}{l}\text { Taft et al., } \\
2005\end{array}$ & Johrei & $\begin{array}{l}\text { SF188 GM (glioblastoma } \\
\text { multiforme humano) }\end{array}$ & $\begin{array}{l}\text { Não há diferença } \\
\text { quanto proliferação e } \\
\text { mortalidade em } \\
\text { relação ao grupo } \\
\text { controle }\end{array}$ \\
\hline $\begin{array}{l}\text { Hall et al., } \\
2007\end{array}$ & Johrei & Células de gliais humanas & $\begin{array}{l}\text { Não há proliferação } \\
\text { em células que } \\
\text { sofreram efeitos de } \\
\text { radiação. }\end{array}$ \\
\hline $\begin{array}{l}\text { Mager et al., } \\
2007\end{array}$ & $\begin{array}{l}\text { Qi gong, } \\
\text { Johrei e } \\
\text { habilidades } \\
\text { inatas }\end{array}$ & $\begin{array}{l}\text { Astrócitos humanos } \\
\text { normais }\end{array}$ & $\begin{array}{l}\text { Não há diferença } \\
\text { estatística na taxa de } \\
\text { mortalidade em } \\
\text { relação ao grupo } \\
\text { controle. }\end{array}$ \\
\hline $\begin{array}{l}\text { Gronowicz et } \\
\text { al., } 2008\end{array}$ & $\begin{array}{c}\text { Toque } \\
\text { terapêutico }\end{array}$ & $\begin{array}{l}\text { Osteoblastos, tenócitos e } \\
\text { fibroblastos }\end{array}$ & $\begin{array}{l}\text { Aumento na } \\
\text { proliferação celular }\end{array}$ \\
\hline $\begin{array}{l}\text { Gronowicz et } \\
\text { al., } 2011\end{array}$ & $\begin{array}{l}\text { Toque } \\
\text { terapêutico }\end{array}$ & $\begin{array}{c}\text { Saos-2 e HOS (linhagens } \\
\text { de osteossarcoma } \\
\text { humano) }\end{array}$ & $\begin{array}{c}\text { Inibição na } \\
\text { proliferação de HOS e } \\
\text { diminuição na } \\
\text { mineralização de } \\
\text { ambas linhagens }\end{array}$ \\
\hline $\begin{array}{l}\text { Yount et al., } \\
2013\end{array}$ & $\begin{array}{c}\text { Não } \\
\text { discriminada }\end{array}$ & U87 (glioblastoma) & $\begin{array}{l}\text { Não há diferença } \\
\text { significativa na } \\
\text { viabilidade celular }\end{array}$ \\
\hline
\end{tabular}




\subsection{PRÁTICAS COMPLEMENTARES E SISTEMA IMUNE}

Muito antes do conceito de sistema imune, praticantes vitalistas ${ }^{\mathrm{c4}}$ acreditavam na habilidade do corpo em ajudar a si mesmo (Goldrosen e Straus, 2004). Diversos estudos demonstram o efeito do Reiki sobre a redução do estresse, dor e ansiedade, entretanto, são poucos aqueles que documentam o efeito sobre marcadores biológicos específicos (Morse e Beem, 2011).

Pesquisas têm evidenciado os efeitos do Reiki, em especial, sobre processos inflamatórios e sobre o sistema imunológico. Wirth et al. (1993), por exemplo, demonstraram a capacidade de redução da dor, por aplicação de Reiki, associada ao acetaminofeno e à prática da técnica de LeShan, em processo inflamatório agudo gerado pela retirada do terceiro molar inferior em um grupo de voluntários de 19 a 28 anos .

Wardell e Engebreston (2001), avaliando efeitos fisiológicos e bioquímicos em resposta à redução de estresse em indivíduos saudáveis, por meio da comparação dos resultados antes e após aplicação de Reiki por 30 minutos, comprovaram que, dentre outros, houve redução significativa dos níveis de ansiedade, aumento, estatisticamente significante, dos níveis de imunoglobulina $A$ salivar e da temperatura da pele, e diminuição da pressão sanguínea e diminuição dos padrões eletromiográficos (Wardell e Engebretson, 2001).

Garé (2008) observou que camundongos tiveram redução significativa do tamanho de granulomas após receberam aplicação de Reiki . Oliveira (2003), por sua vez, ao avaliar o efeito do toque terapêutico em camundongos (controle e intervenção), observou aumento significativo na contagem monocitária e plaquetária no grupo de animais que receberam a intervenção em relação ao grupo controle, assim como a

\footnotetext{
c Práticas vitalistas, segundo Tesser (2009), são aquelas onde a racionalidade médica trabalha com noções de "princípio" ou "energia" vital que interliga o indivíduo interna ou externamente(Carvalho e Lemônica, 1998).
} 
elevação da atividade citotóxica de células não-aderentes com atividade Natural Killer $(\mathrm{NK})^{\mathrm{d} 5}$ e Lymphokine Activated Killerer (LAK)(Oliveira, 2003).

Investigação foi realizada sobre o efeito da meditação prânica em 29 indivíduos saudáveis, divididos em grupos de alta prática (acima de 980 minutos) e baixa prática (menos de 980 minutos). Por uma, cinco ou dez semanas os grupos praticaram a meditação prânica e tiveram o sangue e a saliva coletados para avaliação da fagocitose, da produção de peróxido de hidrogênio e de óxido nítrico pelos monócitos, e a concentração de corticotrofina, de cortisol e de melatonina. Os resultados mostraram que no grupo que praticou a meditação por mais tempo, houve aumento significativo na capacidade fagocitária de neutrófilos e monócitos ( $p=0,01)$, aumento na concentração de peróxido de hidrogênio pelos monócitos e neutrófilos $(p<0,0001)$, e a redução nos níveis plasmáticos de corticotrofina $(p=0,0002)$. Não houve variação estatisticamente significante de nenhuma variável aferida no grupo que praticou a meditação por menos tempo, assim como não houve também alterações na concentração de óxido nítrico, cortisol e de melatonina no grupo que praticou por mais tempo (Fernandes et al., 2012).

Por outro lado, se o Reiki influencia na homeostase do organismo, como poderia atuar em células isoladas do corpo, sem o princípio vital maior? A resposta pode estar na teoria holográfica, onde o holos é a parte que representa o todo. Neste caso a célula representaria o organismo.

Wilber et al. (2002, p.109-10) citam que:

"Cada aspecto do universo é, em si mesmo, um todo, um ser completo, um sistema abrangente por si mesmo, por 'direito nato', contendo dentro de si um depósito completo de informações a seu respeito e, portanto, por menor que sejam as partículas atômicas, elas devem ser consideradas como sistemas vivos, inteligentes e completos" [...] "Uma vez que cada sistema é uma expressão da dinâmica de suas partes, cada sistema holográfico subordinado forma-se, portanto, de muitos outros sistemas completos que, em relação ao conjunto maior, são reconhecidos como partes. Cada uma delas possui inteligência própria, e cada sistema holográfico é energeticamente capaz de conhecer todas as suas várias partes".

\footnotetext{
d Células NK são células participantes do sistema imunológico inato, com alta capacidade citotóxica, sendo importantes no processo de lise de células cancerígenas ou infectadas por vírus (Oliveira, 2003).

e Segundo Oliveira (2003), Lymphokine Activated Killer (LAK) são linfócitos estimulados por interleucina-2(IL-2), que desenvolvem atividade citotóxica inespecífica, apresentando fenótipo de células Natural Killer (NK) ativadas (Oliveira, 2003).
} 
Essa concepção enfatiza a inter-relação e a interdependência essenciais de todos os fenômenos e procura entender a natureza, não só em termos de estruturas fundamentais, mas também em função de um processo dinâmico (Capra, 1982).

\subsubsection{Sistema imune}

A manutenção da estabilidade do meio interno dos seres vivos, frente às variações que ocorrem no meio externo, é crucial, entre outros, para a sua sobrevivência. Em face disto, o processo evolutivo desses seres, proporcionou tanto um sistema voltado à homeostase, quanto desenvolveu formas para que os organismos pudessem se defender de agentes agressores, assim como para promover a restauração do local lesionado (Rang et al., 2007).

O alcance dessa homeostase, nos mamíferos, está sob a responsabilidade da função imunológica que, conceitualmente, divide-se em imunidade inata e imunidade adaptativa, as quais agem conjuntamente, mediadas pro leucócitos (Rang et al., 2007).

A imunidade inata caracteriza-se por defender prontamente o organismo contra vários estímulos, porém de forma limitada. Esta resposta aos agentes agressores não está relacionada ao contato anterior com os mesmos, e é realizada por células, como neutrófilos, células dendríticas, macrófagos e células Natural Killer - NK (Cruvinel et al., 2010).

A imunidade adaptativa tem sua resposta condicionada à ativação de linfócitos e de moléculas solúveis (produzidas por linfócitos). Esta resposta se distingue pelas seguintes propriedades: especificidade, diversidade, memória, expansão clonal, especialização, contração e homeostasia, não-reatividade própria (Abbas e Lichtman, 2009; Cruvinel et al., 2010).

Os leucócitos são um grupo de células (glóbulos brancos) que, além dos neutrófilos, abarcam, também, basófilos, eosinófilos, monócitos e linfócitos, e fazem parte do tecido sanguíneo, constituído, ainda por eritrócitos (glóbulos vermelhos), plaquetas e por uma parte líquida, o plasma. A figura 1 apresenta um esquema da origem leucocitária. 
Figura 1 - Esquema de origem das diversas linhagens de células do Sistema Imunológico.

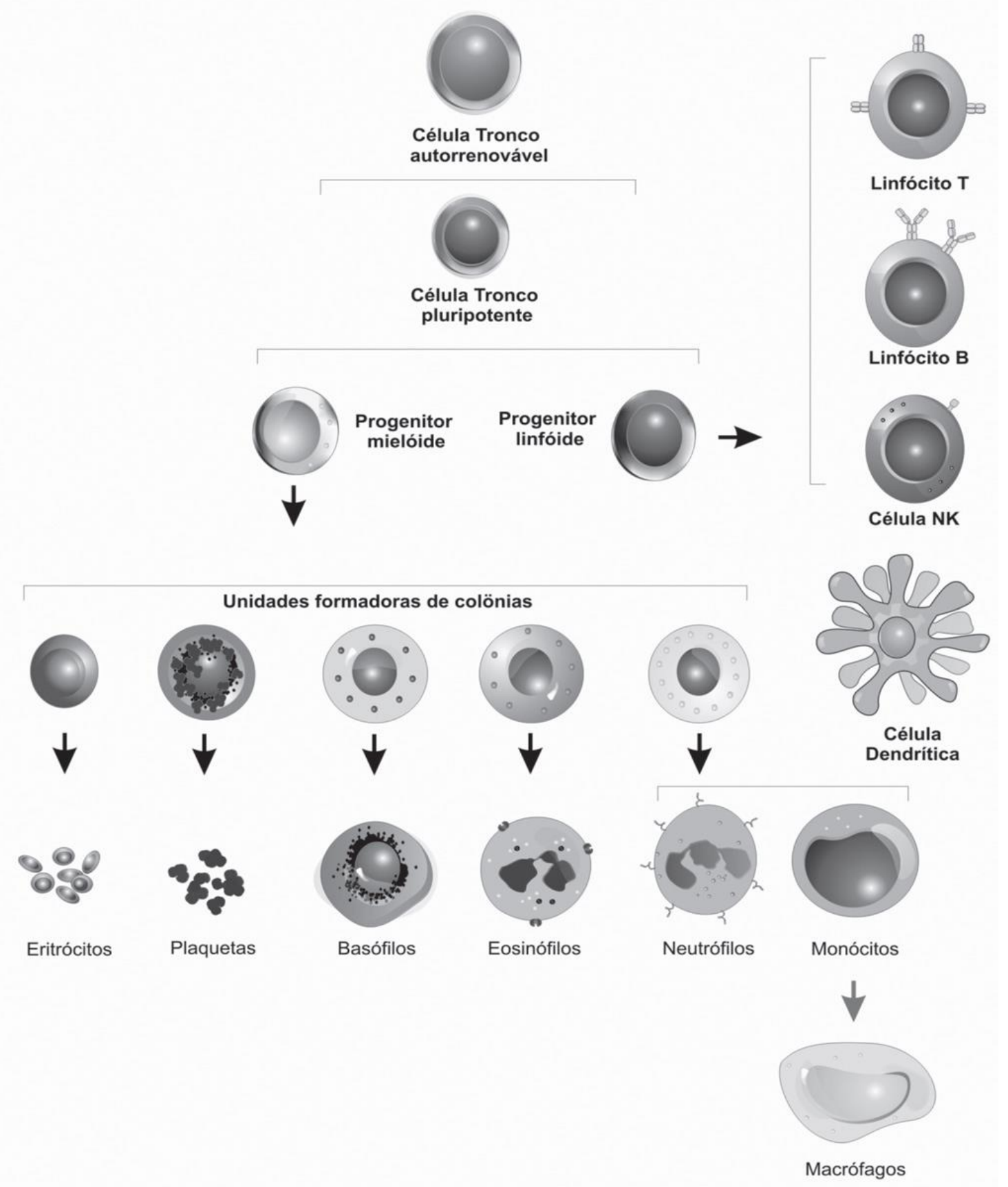

FONTE: CRUVINEL, W. DE M. et al. Immune system: Part I. Fundamentals of innate immunity with emphasis on molecular and cellular mechanisms of inflammatory response. Revista Brasileira de Reumatologia, v. 50, n. 4, p. 434-447, 2010. 
A classificação dos leucócitos se dá pela presença de grânulos específicos (neutrófilos, basófilos e eosinófilos), chamados de granulócitos ou, ausência de grânulos (monócitos e linfócitos), denominados de agranulócitos (Montanari, 2013)

Os neutrófilos são leucócitos polimorfonucleares, que atuam na imunidade inata, assim como também atingem vários aspectos da imunidade adaptativa (Kolaczkowska e Kubes, 2013; Odobasic et al., 2016). Estas células são produzidas na medula óssea, a partir de células precursoras estimuladas por citocinas, sobretudo pelo fator estimulador de colônias de granulócitos (G-CSF), levando cerca de duas semanas para atingirem a maturação. Foi observado que, em condições fisiológicas, os neutrófilos podem ser encontrados, além da medula óssea, também no baço, no fígado e nos pulmões. Desconhece-se o motivo dos neutrófilos estarem concentrados nestes tecidos, entretanto, acredita-se que sejam reservatórios (Kolaczkowska e Kubes, 2013; Santos, 2007)

Nos seres humanos eles correspondem a 50-70\% dos leucócitos circulantes e têm sobrevida média de 8 horas na circulação sanguínea. Alguns estudos sugerem que em condições basais eles podem durar até 5,4 dias na circulação (Kolaczkowska e Kubes, 2013). A obtenção da homeostase dos neutrófilos está relacionada com sua baixa sobrevida e com a taxa de liberação dos mesmos pela medula óssea (Kaplan e Radic, 2012).

O diâmetro do neutrófilo é de cerca de 12 a $14 \mu \mathrm{m}$, comumente, possui núcleo formado por três lóbulos, com variações de dois a cinco (Montanari, 2013). Estas células contêm, ainda, três tipos de grânulos (primários ou azurófilos, específicos ou secundários e terciários), além de glicogênio no citoplasma, para fins de metabolismo anaeróbio, nas situações em que ocorre carência de oxigênio e glicose em tecidos sem vascularização (Cruvinel et al., 2010; Montanari, 2013).

Cruvinel et al. (2010) descrevem os principais componentes, respectivos a cada tipo de grânulo, a saber: primários (mieloperoxidase, defensinas, proteína de aumento da permeabilidade celular, catepsina G, elastase neutrofílica), secundários (lactoferrina) e terciários (gelatinases e catepsinas). As estruturas compostas por fibras de cromatina, peptídeos antimicrobianos, derivados dos grânulos, e enzimas como a elastase, catepsina $\mathrm{G}$ e a mieloperoxidase (MPO) são conhecidas como armadilhadas extracelulares (NETs -Neutrophil Extracelular Traps) (Kaplan e Radic, 2012). 
Ainda, é reconhecida a existência de diferentes tipos de neutrófilos, cada um com diferentes perfis quanto a expressão de proteínas de membrana, como os Toll-like receptors (TLR), citocinas e quimiocinas, e teriam diferentes ações sobre infecção, inflamação e imunologia do câncer (Kolaczkowska e Kubes, 2013).

Os fagócitos, presentes nos macrófagos e neutrófilos, são atraídos para o local da inflamação por interleucinas, fatores quimiotáticos e substâncias vasoativas. $\mathrm{Na}$ inflamação aguda, os neutrófilos são responsáveis pela ação contra agentes infecciosos, sendo a primeira linha de frente do organismo (Kaplan e Radic, 2012).

O deslocamento dos neutrófilos para os locais da inflamação se dá por mecanismos que envolvem, a rolagem dos mesmos pelo endotélio ativado, diapedese, adesão e saída do vaso sanguíneo, com consequente migração do neutrófilo por entre as células, até atingir o sítio da inflamação (Santos, 2007). Estes mecanismos são possíveis devido à estabilidade alcançada na interação entre os neutrófilos e as moléculas de adesão ativadas do endotélio inflamado, como as integrinas, as selectinas e as moléculas de adesão intracelular - ICAM (intercellular adhesion molecule). Após a referida interação ter ficado estável, o neutrófilo consegue se deslocar para o espaço extra vascular, pela ação de outro tipo de molécula de adesão - PECAM (platelet endothelium adhesion molecule) (Rang et al., 2007).

O neutrófilo também libera espécies reativas de oxigênio (ânion superóxido, peróxido de hidrogênio, radicais hidroxila e hipoclorito), enzimas proteolíticas, para atuarem contra os patógenos, óxido nítrico (NO) (Cristovam et al., 2010). O NO é uma substância pró-inflamatória, que possui efeito vasodilatador, permitindo o extravasamento de proteína e fluídos (Garé, 2008).

Um papel importante desempenhado pelos neutrófilos é o de controlar bactérias e fungos no sítio da infecção, reconhecendo-os e destruindo-os. Estas funções são possíveis pela habilidade dos mesmos em migrarem pela corrente sanguínea até o local em que se encontram os patógenos (Thieblemont et al., 2016). Tal processo, de acordo com (Rang et al., 2007), ocorre pela liberação de quimiotaxinas (tanto liberadas pelo patógeno, quanto por células como macrófagos).

O processo de fagocitose dos microrganismos pelos neutrófilos acontece quando estes os envolvem com pseudópodos, que se fundem, e o microrganismo é mantido dentro do vacúolo. Na sequência os grânulos específicos, evacuam seu conteúdo 
dentro do vacúolo, assim como também há liberação, pelos grânulos azurófilos, de enzimas e NETs destinadas à morte e digestão de bactérias e fungos (Figura 2) (Junqueira e Carneiro, 2011).

Figura 2 - Esquema dos mecanismos utilizados pelos neutrófilos para a morte de patógenos.

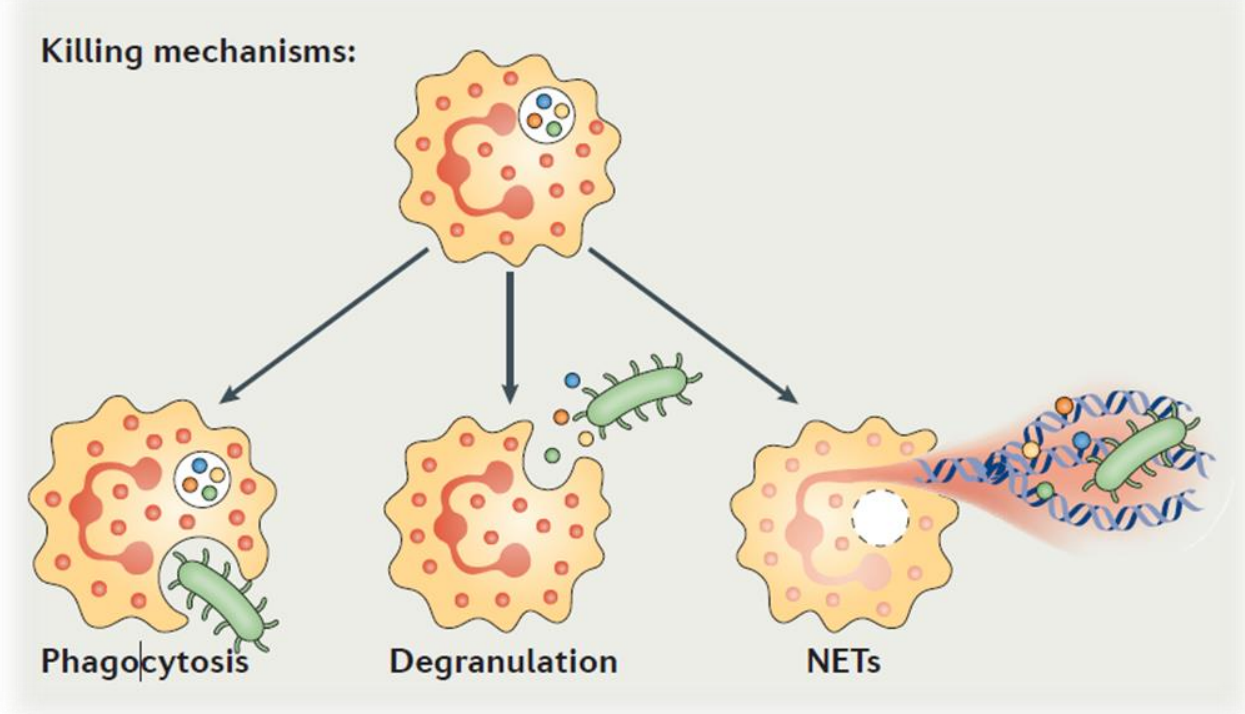

FONTE: KOLACZKOWSKA, E.; KUBES, P. Neutrophil recruitment and function in health and inflammation. Nature Reviews Immunology, v. 13, n. 3, p. 159-175, 25 fev. 2013.

Entre $20-60 \%$ dos neutrófilos eliminam NETs de 2-4h após estimulação microbiana e proteína quinase C. O NET imobiliza patógenos, prevenindo que se disseminem, mas também facilita a fagocitose dos micro-organismos capturados. Supõe-se que os NETs possam agir de diversas formas: por atuação microbicida direta, por meio de histonas antimicrobianas e proteases; facilitando a fagocitose e prevenindo a disseminação dos micro-organismos no corpo. A liberação dos NETs pode ser feita por diversos estímulos, incluindo citocinas pró-inflamatórias como TNF-a e IL-8, plaquetas, células endoteliais ativadas, NO e cristais de urato monossódico e anticorpos. Dois mecanismos são propostos para os NETs: a NETosis, uma forma de morte celular onde a célula libera cromatina descondensada e conteúdo granular para o meio extracelular; e o outro, a liberação de DNA mitocondrial serina proteases, sem associação com a morte celular (Kaplan e Radic, 2012; Kolaczkowska e Kubes, 2013). 
A MPO, de interesse para o presente estudo, é uma hemoproteína glicosilada, uma enzima encontrada nos grânulos azurofílicos dos neutrófilos e compõe cerca de 5\% do peso sólido da célula. A enzima atua na formação de espécies reativas de oxigênio (EROs), e há indicativos de que produtos gerados por essas reações, catalisadas pela MPO, tenham atuação na sinalização de vias da inflamação. Diante da exposição da MPO ao peróxido de hidrogênio $\left(\mathrm{H}_{2} \mathrm{O}_{2}\right)$ e a um intermediário de baixo peso molecular (como cloreto, brometo, tiocianato, tirosina e nitrito) ocorre catalisação e formação de EROs como ácido hipobromoso ( $\mathrm{HOBr}$ ), ácido hipotiociânico ( $\mathrm{HOSCN})$, radical tirosil, intermediários reativos de nitrogênio e, principalmente ácido hipocloroso ( $\mathrm{HOCl})$. Este tem importante efeito microbicida sobre os patógenos fagocitados (Odobasic et al., 2016).

A deficiência de MPO, em humanos, aumenta a susceptibilidade à infecção por fungos, em especial por Candida albicans e outras diversas infecções, como $S$. aureus e S.pneumoniae. Na ausência da MPO, vias alternativas são super expressas, como a maior produção de outras EROs, como o NO, um aumento na atividade de proteases granulares neutrofílicas e na atividade fagocitária e na degranulação, além de aumentar a resposta imune adaptativa (Odobasic et al., 2016).

A MPO também possui papel em outras funções do neutrófilo. Ela é necessária para a liberação das NETs, faz parte de sua composição e é enzimaticamente ativa. A MPO interage com as células dendríticas, pressupondo-se que podem interferir na imunidade adaptativa. A MPO depositada pelos neutrófilos nos linfonodos pode inibir a ativação da célula dendrítica e a subsequente resposta da imunidade por células $T$. Além disso, produtos gerados a partir do $\mathrm{HOCl}$ são capazes de ativar citocinas, a ativação de quinases e outras enzimas (Odobasic et al., 2016). 
Considerando que estudos têm evidenciado os efeitos do Reiki sobre processos inflamatórios e sobre o sistema imunológico, que os neutrófilos são células fundamentais neste processo, e que a aplicação da técnica Reiki em células humanas isoladas, justifica-se pela teoria holográfica, propôs-se este estudo, com o objetivo de avaliar o efeito da aplicação do Reiki sobre neutrófilos humanos in vitro, mensurandose dois aspectos deste tipo de célula: a viabilidade celular e a atividade da enzima mieloperoxidase.

\section{HIPÓTESE}

A aplicação de Reiki, em neutrófilos humanos in vitro, aumenta a viabilidade celular e a atividade da enzima mieloperoxidase destas células. 
4 MÉTODOS 


\section{MÉTODOS}

\subsection{TIPO DE ESTUDO}

Estudo experimental in vitro, duplo cego (pesquisador e estatístico), com abordagem quantitativa.

\subsection{LOCAL DO ESTUDO}

Laboratório de Fisiologia Celular e Biologia Molecular da Universidade Cruzeiro do Sul - Campus Anália Franco - São Paulo - SP.

\subsection{MATERIAIS}

A seguir, são apresentados os equipamentos, os materiais e as soluções utilizadas nos ensaios:

\subsubsection{Equipamentos}

Centrífuga Thermo Scientific - SORVAL - ST 16R - Voltagem de $230 \mathrm{~V}$; Frequência de 50 / 60 Hz; Corrente de 8 A; 1440 W; Micro centrífuga HT - 6000 RPM - Modelo CM - 610; Microscópio óptico; Câmara de Fluxo Laminar; Equipamento de Banho Seco com agitação; Espectrofluorímetro Tecan (Salzburg, Áustria), Incubadora REVCO ULTIMA II. 


\subsubsection{Materiais utilizados}

Escalpe para coleta de sangue com dispositivo de segurança (BD Vacutainer ${ }^{\circledR}$ Safety-lok) ; Tubo para coleta de sangue a vácuo (capacidade de $4,5 \mathrm{~mL}$, contendo $0.1 \mathrm{mM}$ EDTA); Pipeta descartável tipo Pasteur; Micropipetas (com variadas capacidades); Tubo de centrifugação (tipo Falcon) de fundo cônico (capacidades de $15 \mathrm{~mL}$ e de $50 \mathrm{~mL}$ ); Câmera de Neubauer; Lamínula para Câmara de Contagem; Microtubo de centrifugação tipo Eppendorf (capacidade de 1,5 mL); Placa estéril para cultura celular ( $35 \mathrm{~mm}$ X $10 \mathrm{~mm}$ ) e Placa branca com 96 poços (wells), para o ensaio de quimiluminescência.

\subsubsection{Soluções e meios}

PBS - Tampão Fosfato Salino (133,8 mM de $\mathrm{NaCl}, 2,7 \mathrm{mM}$ de $\mathrm{KCl}, 0,9 \mathrm{mM}$ de $\mathrm{KH} 2 \mathrm{PO} 4,6,4 \mathrm{mM}$ de $\mathrm{Na}_{2} \mathrm{H}_{2} \mathrm{PO}_{2}$, em pH 7,4); Solução de Hemólise $(150,0 \mathrm{mM}$ de $\mathrm{NH}_{4} \mathrm{Cl}, 10,0 \mathrm{mM}$ de NaHCO2, 0,1 mM de EDTA, em pH 7,4); Histopaque®-1077 g/mL (Sigma - Aldrich); Corante Azul de Tripan (1,0\% em PBS); Meio de cultura RPMI 1640, suplementado com $10 \%$ de soro fetal bovino, $20 \mathrm{mM}$ de Hepes, 2,0 mM de glutamina e antibióticos (100 Unidades de estreptomicina/mL e 200 Unidades de penicilina/mL); Solução de Tyrode ( $\mathrm{NaCl}$ 137,00 mM; KCl 2,70 mM; CaCl2.2H2O 1,36 mM; MgCl2.6H2O 0,50 mM; NaH2PO4.H2O 0,36 mM; NaHCO3 11,90 mM; Glicose 5,50 mM); PMA (1 Forbol-12 Miristato-13-Acetato) Peróxido de Hidrogênio $\left(\mathrm{H}_{2} \mathrm{O}_{2}\right) \mathrm{e}$ Luminol (5-amino-2,3-diidroftalazina-1,4-diona) como marcador de quimiluminescência. 


\subsection{AMOSTRAS DE SANGUE}

Os neutrófilos foram isolados de sangue humano obtido de cinco voluntários saudáveis. De cada voluntário retirou-se $20 \mathrm{~mL}$ de sangue por punção venosa periférica, para um ensaio completo com grupo controle e grupo experimental. Portanto, ao final, totalizaram cinco ensaios.

Foram estabelecidos critérios para o recrutamento de doadores voluntários. Critérios de inclusão: adulto, do sexo masculino (para evitar possível viés de alterações hormonais, frequentes em mulheres), saudável, na faixa dos 20 aos 40 anos.

Critérios de exclusão: problema de saúde referido, uso de medicamentos, uso de terapia complementar (como terapias energéticas, fitoterapia, meditação e outras).

O estudo foi divulgado no ambiente da pesquisa. Para cada voluntário, foi exposto o objetivo do estudo e, perante a aceitação em participar da pesquisa, foi assinado o Termo de Consentimento Livre e Esclarecido (TCLE) (APÊNDICE 1), após a certificação de que este atendia aos critérios de inclusão e de exclusão previamente estabelecidos. Foi aplicada uma entrevista (APÊNDICE 2), a fim de verificar as condições sociodemográficas e de saúde de cada um dos participantes.

\subsection{ISOLAMENTO DE NEUTRÓFILOS}

O processo de isolamento dos neutrófilos, separação para cultivo e contagem foi realizado segundo Böyum (1968). Após a punção periférica, os $20 \mathrm{~mL}$ de sangue coletados foram transferidos para um tubo de coleta a vácuo contendo $0.1 \mathrm{mM}$ EDTA. Na sequência, o sangue foi transferido para um tubo cônico tipo Falcon (50 mL), sendo diluído, na proporção de 1:1, com solução Tampão Fosfato Salino (PBS).

Para a separação do plasma, foram preparados quatro tubos cônicos tipo Falcon ( $15 \mathrm{~mL}$ ), colocando-se em cada um, $5 \mathrm{~mL}$ de Histopaque ${ }^{\circledR}-1077 \mathrm{~g} / \mathrm{mL}$ (para separação por gradiente de densidade). O volume de cada tubo foi, então, completado para 15 
$\mathrm{mL}$, e para tal foram utilizadas pipetas tipo Pasteur para colocar, de modo lento, 10 $\mathrm{mL}$ da solução de sangue com PBS sobre o Histopaque®-1077 g/mL.

Os tubos foram colocados na Centrífuga Thermo Scientific e realizada a centrifugação por 30 minutos, a $1400 \mathrm{~g}$, em temperatura ambiente.

Figura 3 - Represe9ntação dos quatro tubos crônicos tipo Falcon (15 mL) após a centrifugação, com o conteúdo sedimentado e o sobrenadante. São Paulo, 2017.

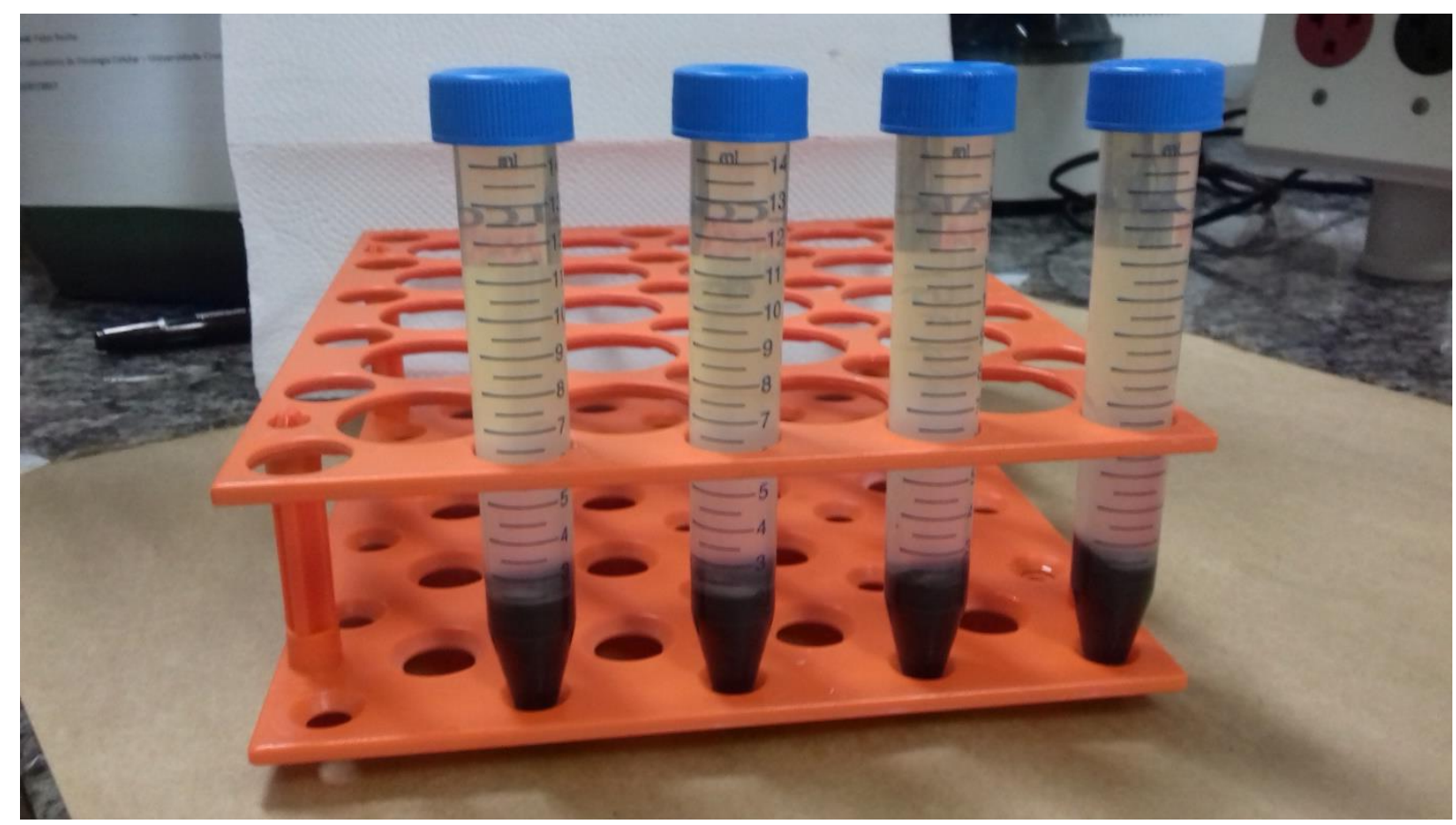

FONTE: VANNUCCI, L. (2017).

Após esta etapa (Figura 3), foi retirado o sobrenadante (Histopaque $\AA$, plasma e camada intermediária) dos tubos. O conteúdo sedimentado, composto por neutrófilos e eritrócitos, foi transferido para um tubo tipo Falcon $(50 \mathrm{~mL})$, e seu volume completado para $50 \mathrm{~mL}$, com solução de hemólise, permanecendo em repouso por 10 minutos, e na sequência, centrifugado por 10 minutos, a $1400 \mathrm{~g}$, em temperatura de $4^{\circ} \mathrm{C}$. Ao ser constatada a formação do pellet de neutrófilos (Figura 4), desprezou-se o sobrenadante com os eritrócitos hemolisados. 
Figura 4 - Representação do pellet de neutrófilos. São Paulo, 2017.

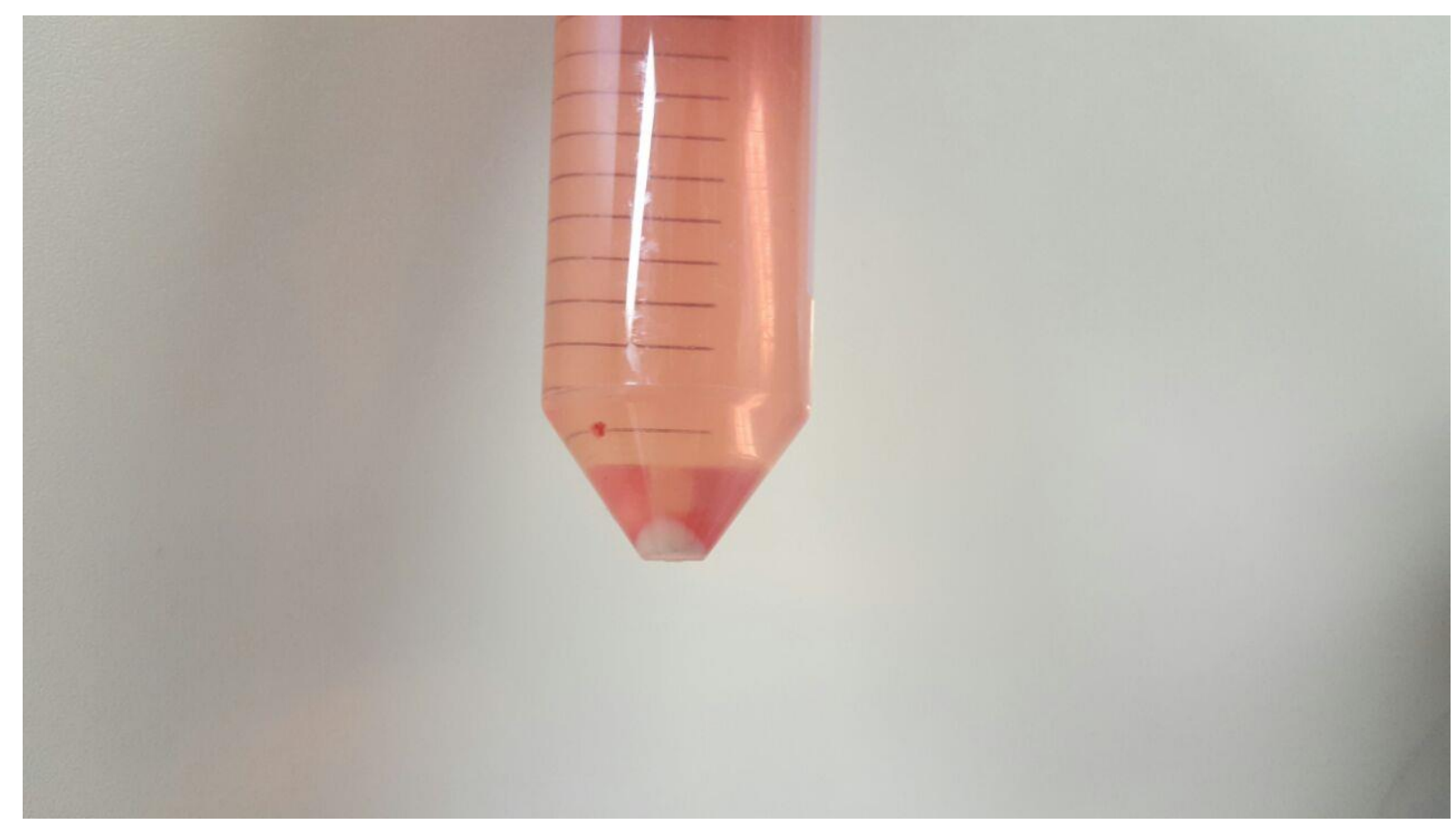

FONTE: VANNUCCI, L. (2017).

O pellet foi ressuspendido em solução de hemólise e o processo para a lise dos eritrócitos foi repetido mais uma vez (ou mais, no caso da permanência de eritrócitos ainda não hemolisados). Na sequência, o pellet foi ressuspendido com PBS, completando-se um volume de $50 \mathrm{~mL}$ e, em seguida, centrifugado por 10 minutos, a $1400 \mathrm{~g}$, em temperatura de $4^{\circ} \mathrm{C}$. Novamente, foi descartado o sobrenadante ao final da centrifugação, restando somente os neutrófilos sedimentados (pellet) no tubo.

\subsection{CULTIVO DE NEUTRÓFILOS}

$\mathrm{Na}$ sequência, em capela de fluxo laminar, iniciou-se o processo de preparação para o cultivo celular dos neutrófilos isolados no tubo, por meio da ressuspensão do pellet em $1000 \mu \mathrm{L}$ do meio de cultura RPMI - 1640, com complementação do volume com mais $4 \mathrm{~mL}$ desse meio de cultura, totalizando $5 \mathrm{~mL}$. Foi realizado o cálculo do volume a ser retirado (meio de cultura com neutrófilos) para que em cada placa fossem alocadas $1 \times 10^{6}$ células. Para tal, do volume de $5 \mathrm{~mL}$ foi retirada uma alíquota de 10 
$\mu \mathrm{L}$. A esta, foram acrescentados $10 \mu \mathrm{L}$ de corante Azul de Tripan 1,0\% (em PBS) objetivando a diferenciação de células vivas e mortas, pela exclusão do corante pelas células viáveis. Utilizando-se microscópio óptico, com objetiva de 40X, as células foram contadas em câmara de Neubauer e o número de células vivas, mortas, e totais foram calculadas, e o resultado aplicado conforme fórmula, a seguir (Peres e Curi, 2005):

$$
\frac{№ \text { de células }}{N^{\circ} \text { de quadrantes }} \times \text { diluiç̧ão } \times 10^{4}=N \text { o de células } / \mathrm{ml}
$$

Após estabelecido o volume necessário para o cultivo de $1 \times 10^{6}$ células por placa, foram reservadas, em capela de fluxo laminar, oito placas para cultura. Cada uma delas foi preenchida com o volume calculado (proveniente do tubo com neutrófilos e $5 \mathrm{~mL}$ de meio de cultura), complementado com quantidade de meio de cultura RPMI - 1640, suficiente para totalizar $1000 \mu \mathrm{L} /$ placa. Na sequência, as placas foram tampadas e retiradas da Câmara de fluxo laminar.

Em seguida, conforme descrito no item 4.7, as placas foram identificadas em grupos I e II, por uma pessoa que colaborou no cegamento do pesquisador, para receberem ou não a aplicação do Reiki. Enquanto um grupo cegado foi submetido a aplicação de Reiki, o outro grupo permaneceu o mesmo período de tempo em meio ambiente a uma distância de 1,5m da placa sob intervenção. Após os 15 minutos de intervenção na placa experimental, seis placas (duas destinadas ao ensaio da MPO e quatro correspondentes aos tempos de 24 e 48 horas) foram incubadas para cultivo em estufa a $37^{\circ} \mathrm{C}$, em $5 \%$ de $\mathrm{CO}_{2}$, por 48 horas, conforme Morandi et al. (2014) . As duas placas (grupos I e II) do primeiro dia do ensaio (tempo zero) foram separadas para verificação da viabilidade celular, porém, para evitar que a placa contada em segundo lugar, permanecesse por mais tempo em temperatura ambiente do que a primeira (condição que poderia propiciar a morte celular), as mesmas ficaram na incubadora, juntamente com o restante das placas, durante o período de contagem da primeira placa. Além desse cuidado, também os grupos (I e II) que foram contados em primeiro lugar, tiveram esta ordem alternada para cada ensaio. Deste modo, no primeiro ensaio (três dias) o grupo I foi contado em primeiro lugar, no segundo ensaio o grupo II foi contado em primeiro lugar, e assim por diante. 
Tais medidas foram adotadas após a realização de um teste piloto com três ensaios, nos quais foi observado um menor número de células vivas no grupo em que era realizada a contagem em segundo lugar, o que se justifica pelo fato da maior demanda de tempo para a contagem em triplicata de cada placa. Desta forma, estabeleceu-se que além da alternância da contagem dos grupos por ensaio, o grupo contado em segundo lugar deveria sempre permanecer na incubadora até que terminasse a contagem do primeiro.

\subsection{MODELO EXPERIMENTAL}

Para cada ensaio foram preparadas oitos placas de cultivo de neutrófilos, sendo quatro para o grupo experimental e quatro para o grupo controle (Figura 5).

Figura 5 - Quatro das oito placas preparadas para cultivo celular, referentes a um dos grupos. São Paulo, 2017.

FONTE: VANNUCCI, L. (2017).

O grupo experimental recebeu aplicação de Reiki, em temperatura ambiente, por meio da imposição de mãos, a $15 \mathrm{~cm}$ de distância por 15 minutos. A aplicação de Reiki foi realizada uma vez ao dia, durante três dias consecutivos, em sessões a cada 
24 horas, por uma terapeuta graduada no nível dois (escola de Reiki "tradicional"), com experiência de 21 anos de prática na técnica.

O grupo controle permaneceu pelo mesmo tempo e nas mesmas condições ambientais do grupo de intervenção, a uma distância de, aproximadamente, um metro e meio do mesmo, sem receber a aplicação de Reiki.

Antes de começar o ensaio, um colaborador do laboratório ficou responsável por identificar cada uma das placas preparadas para o cultivo de neutrófilos, por meio de uma etiqueta colocada na parte externa e inferior das mesmas, nomeando-as em "Grupo I" e em "Grupo II", de modo que o pesquisador, durante todo o processo do ensaio não soubesse qual a designação dada a cada grupo, permanecendo "cegado", tanto na realização da intervenção, quanto nas análises posteriores. Destaca-se que para tal, o referido colaborador, sem a presença do pesquisador, foi o responsável pela distribuição das placas dos grupos experimental e controle no ambiente da pesquisa, dispondo-os conforme a distância preconizada, para que em seguida 0 pesquisador pudesse entrar no ambiente e realizar a intervenção, sem conhecer a qual grupo estaria aplicando a técnica Reiki. Após cada intervenção, o pesquisador se retirava da sala, para que o colaborador pudesse reunir novamente as placas de ambos os grupos, de modo que ao fornecê-las ao pesquisador, para fins de verificação da viabilidade celular (contagem das células na câmara de Neubauer), o mesmo não fosse capaz de reconhecer em qual destes grupos havia realizado a intervenção. $O$ mesmo foi feito para a realização do ensaio da atividade da enzima mieloperoxidase. A figura 6 apresenta o fluxo experimental realizado em cada ensaio. 
Figura 6 - Diagrama do fluxo de cada ensaio. São Paulo, 2017.

\section{T Oh}

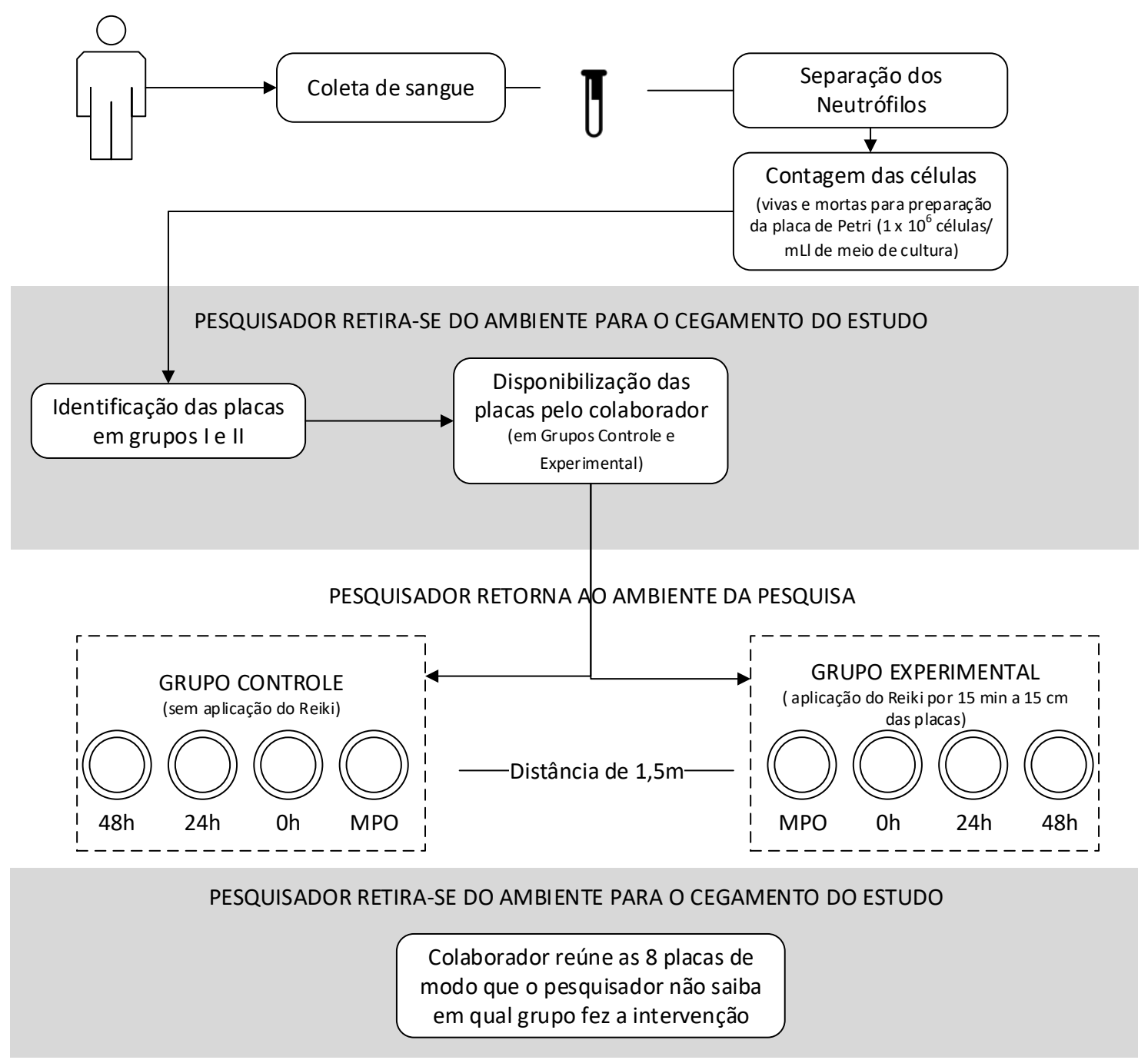

PESQUISADOR RETORNA AO AMBIENTE DA PESQUISA

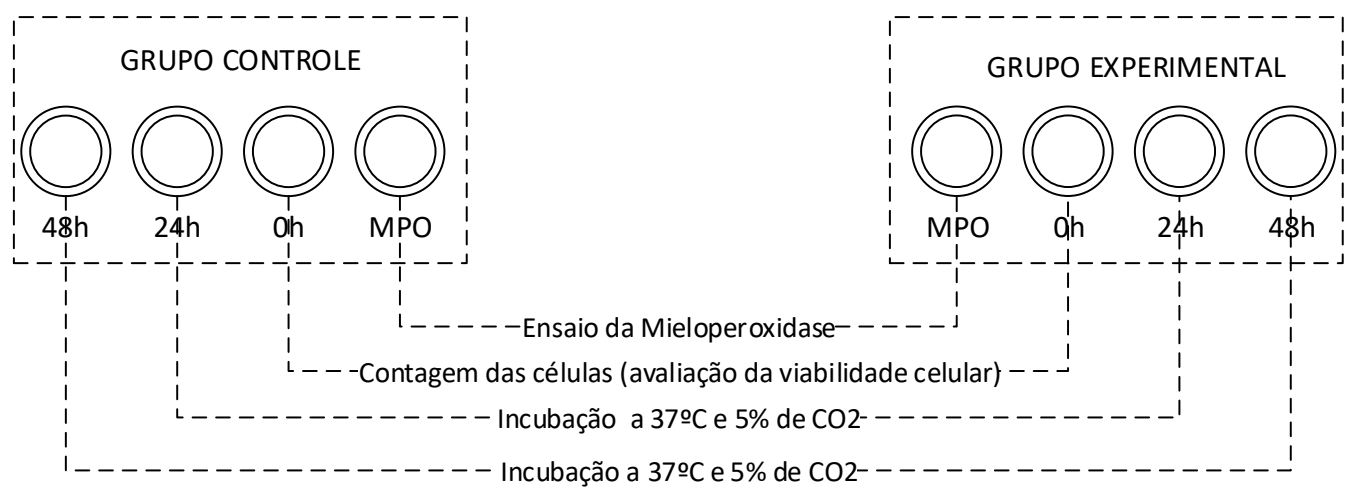


Figura 6 - Diagrama do fluxo de cada ensaio. São Paulo, 2017 (continuação).

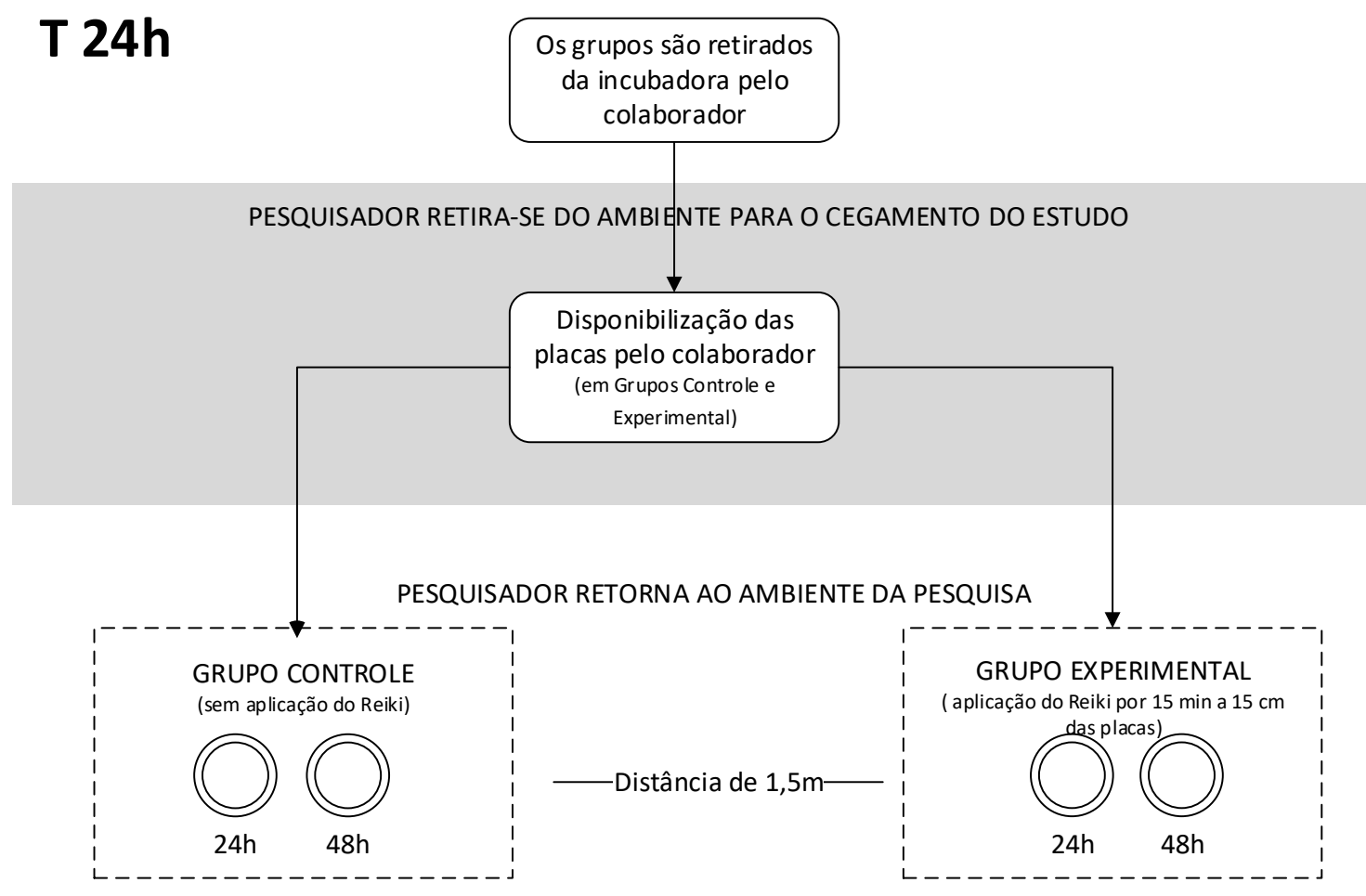

PESQUISADOR RETIRA-SE DO AMBIENTE PARA O CEGAMENTO DO ESTUDO

Colaborador reúne as 4 placas de modo que o pesquisador não saiba em qual grupo fez a intervenção

PESQUISADOR RETORNA AO AMBIENTE DA PESQUISA

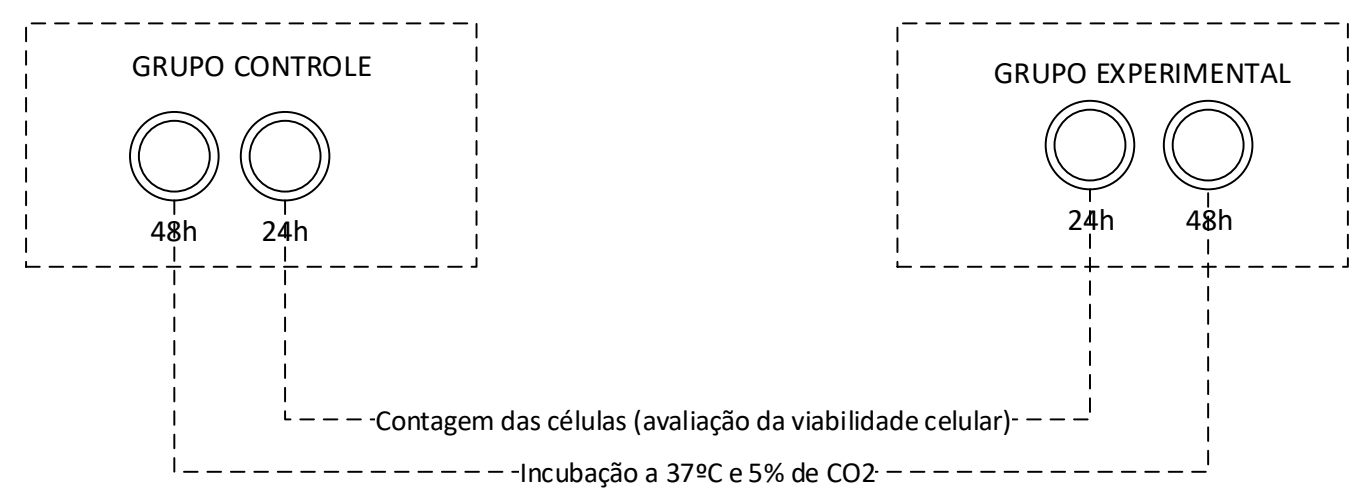


Figura 6 - Diagrama do fluxo de cada ensaio. São Paulo, 2017 (continuação).

\section{T 48h}

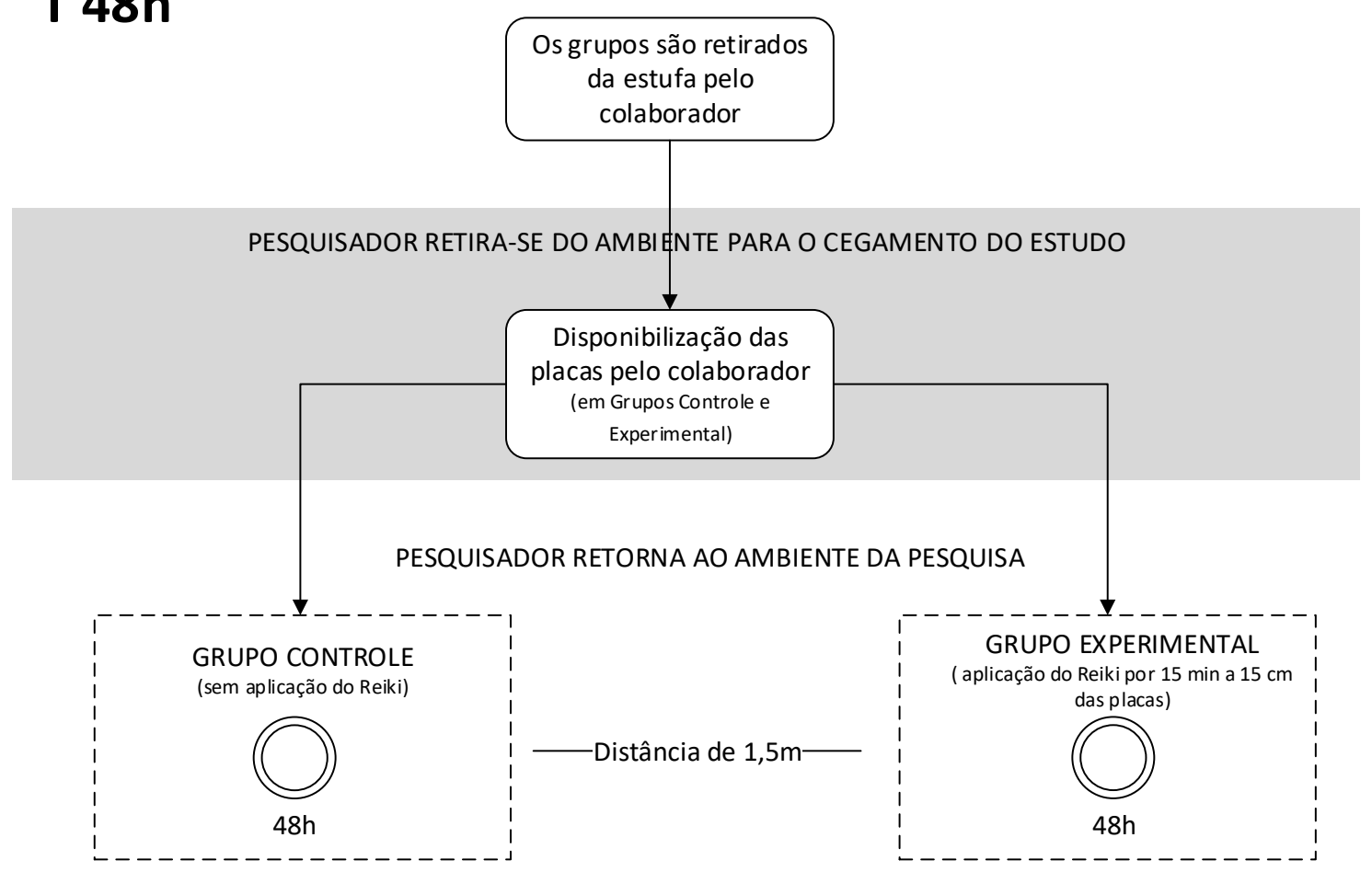

PESQUISADOR RETIRA-SE DO AMBIENTE PARA O CEGAMENTO DO ESTUDO

Colaborador reúne as 2 placas de modo que o pesquisador não saiba em qual grupo fez a intervenção

PESQUISADOR RETORNA AO AMBIENTE DA PESQUISA

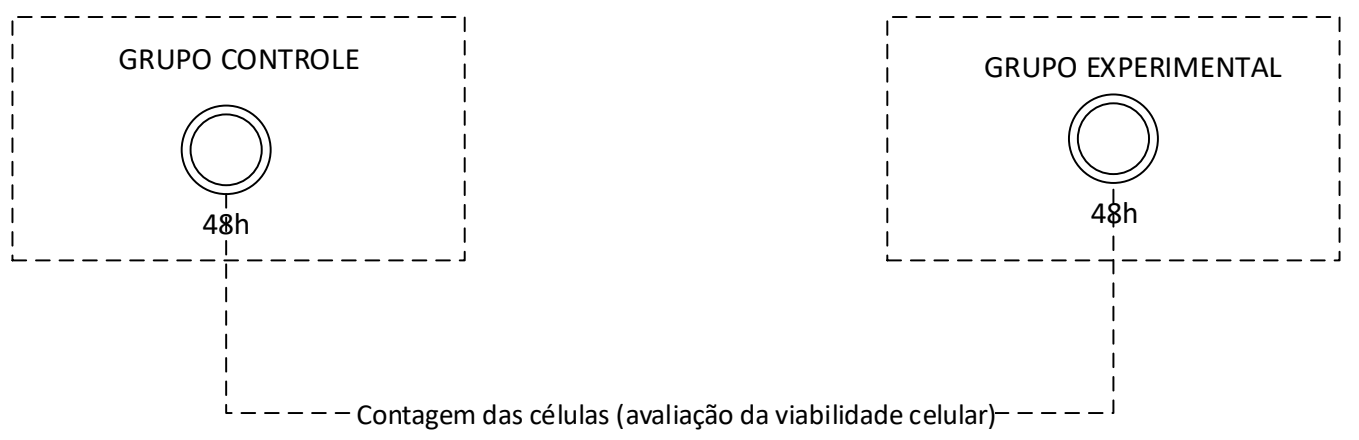

FONTE: VANNUCCI, L. (2017). 


\subsection{DESFECHO 1 - VIABILIDADE CELULAR}

A viabilidade dos neutrófilos foi avaliada pela técnica de exclusão do corante azul de Tripan (1,0\% em PBS), que permite diferenciar células vivas e mortas pela exclusão do corante pelas células viáveis. As células foram contadas em câmara de Neubauer e o número de células vivas, mortas, e totais foram calculados. A análise foi feita utilizando-se a média obtida em cada triplicata.

\subsection{DESFECHO 2 - DOSAGEM DA ENZIMA MIELOPEROXIDASE}

O processo para a avaliação da atividade da enzima mieloperoxidase foi realizada uma única vez em cada ensaio, em duplicata, no primeiro dia. As placas identificadas como "MPO" (dos dois grupos) permaneceram em incubadora, após a aplicação de Reiki na placa experimental, enquanto a outra também permanecia no ambiente, até a finalização da verificação da viabilidade celular das placas nomeadas como tempo "zero h".

Conforme Hatanaka, et al. (2006), a liberação da enzima mieloperoxidase (MPO) pelos neutrófilos ( $1 \times 10^{6}$ células/well), foi dosada pela exposição destes a $60 \mathrm{ng} / \mathrm{well}$ de PMA por $30 \mathrm{~min}$, a $37^{\circ} \mathrm{C}$. Posteriormente à incubação, foi realizada a imersão do meio em gelo e a centrifugação a $500 \times \mathrm{g}$ por $10 \mathrm{~min}$, a $4^{\circ} \mathrm{C}$, para a separação do sobrenadante das células, com a finalidade de aferir a atividade da MPO. O ensaio foi realizado em solução de Tyrode, $\mathrm{H}_{2} \mathrm{O}_{2}(0,1 \mathrm{mM})$ e luminol $(1 \mathrm{mM})$ a $37^{\circ} \mathrm{C}$, em um volume final de $0,3 \mathrm{ml}$ (Hatanaka et al., 2006). Após, a luminescência foi monitorada em espectrofluorímetro Tecan (Salzburg, Áustria), e expressa em Unidades Relativas de Luminescência. 


\subsection{ANÁLISE ESTATÍSTICA}

A análise descritiva e inferencial de cada fase proposta foi realizada utilizando o software estatístico $R$ versão 3.4.1. Utilizou-se um modelo de equações de estimação generalizadas (GEE) para distribuição binomial nos dados de viabilidade para comparar os grupos longitudinalmente e um modelo de ANOVA para medidas repetidas não paramétrico para o MPO. Adotou-se o nível de significância de 5\%.

\subsection{ASPECTOS ÉTICOS}

O estudo seguiu os aspectos éticos da resolução 466/2012 do CONEP e ao voluntário do estudo foi fornecido o Termo de Consentimento Livre e Esclarecido TCLE (Apêndice 2). O estudo foi submetido ao Comitê de Ética em Pesquisa da Escola de Enfermagem - USP e aprovado com o Número do Parecer: 1.780.939. 
5 RESULTADOS 


\section{RESULTADOS}

A avaliação da viabilidade celular foi contada em triplicata e o valor considerado foi a média das três aferições (Tabela 5.1).

Tabela 5.1 - Média, desvio padrão e erro padrão da viabilidade celular, dada como porcentagem de células vivas, considerando as triplicatas para cada um dos cinco ensaios considerando seus valores para o grupo controle e experimental em relação a cada tempo aferido - 0h, $24 \mathrm{~h}$ e $48 \mathrm{~h}$ do ensaio.

São Paulo, 2017.

\begin{tabular}{cccccccc}
\hline \multirow{2}{*}{ Tempo } & Ensaio & Média & $\begin{array}{c}\text { Controle } \\
\text { Desvio } \\
\text { Padrão }\end{array}$ & $\begin{array}{c}\text { Erro } \\
\text { Padrão }\end{array}$ & Média & $\begin{array}{c}\text { Experimental } \\
\text { Desvio } \\
\text { Padrão }\end{array}$ & $\begin{array}{c}\text { Erro } \\
\text { Padrão }\end{array}$ \\
\hline \multirow{4}{*}{ Oh } & 1 & 74,44 & 8,39 & 4,84 & 73,40 & 4,52 & 2,61 \\
& 2 & 81,93 & 12,38 & 7,15 & 82,47 & 10,81 & 6,24 \\
& 3 & 73,86 & 3,94 & 2,27 & 79,69 & 7,31 & 4,22 \\
& 4 & 73,93 & 6,10 & 3,52 & 82,88 & 1,22 & 0,70 \\
& 5 & 78,91 & 7,38 & 4,26 & 87,53 & 6,57 & 3,79 \\
& 1 & 73,88 & 9,40 & 5,43 & 81,97 & 3,32 & 1,92 \\
& 2 & 68,23 & 5,13 & 2,96 & 84,80 & 4,64 & 2,68 \\
& 3 & 63,56 & 11,06 & 6,38 & 76,63 & 2,71 & 1,57 \\
& 4 & 56,71 & 9,67 & 5,58 & 74,87 & 12,36 & 7,13 \\
& 5 & 71,33 & 7,85 & 4,53 & 84,45 & 8,86 & 5,12 \\
& 1 & 80,41 & 5,91 & 3,42 & 79,94 & 6,47 & 3,73 \\
& 2 & 62,30 & 9,94 & 5,74 & 79,72 & 4,10 & 2,37 \\
& 3 & 63,54 & 7,25 & 4,19 & 79,44 & 7,59 & 4,38 \\
& 3 & 49,71 & 47,59 & 2,75 & 88,44 & 3,12 & 1,80 \\
& 4 & 71,76 & 8,49 & 4,90 & 73,67 & 6,77 & 3,91 \\
& 5 & & & & & & \\
\hline
\end{tabular}

Observou-se de modo geral que o percentual médio de células viáveis foi quantitativamente maior no grupo experimental para quase todos os ensaios, exceto para o ensaio 1 do T0 e T48h.

A representação dos resultados da Tabela 5.12 no formato de figura (Gráfico 1) mostra que no grupo controle, diferentemente dos demais ensaios controle, houve um aumento da viabilidade celular com T48h no ensaio 1. Nos demais ensaios controle, 
com o decorrer do tempo houve diminuição ou manutenção do número de células viáveis. No grupo experimental, para alguns ensaios, houve aumento da viabilidade celular em T24h e em outros em T48h.

Gráfico 1 - Representação gráfica da média e erro padrão da viabilidade celular, dada como porcentagem de células vivas, considerando as triplicatas para cada um dos cinco ensaios considerando seus valores para o grupo controle e experimental em relação a cada tempo aferido - 0h, $24 \mathrm{~h}$ e $48 \mathrm{~h}$ do ensaio. São Paulo, 2017.

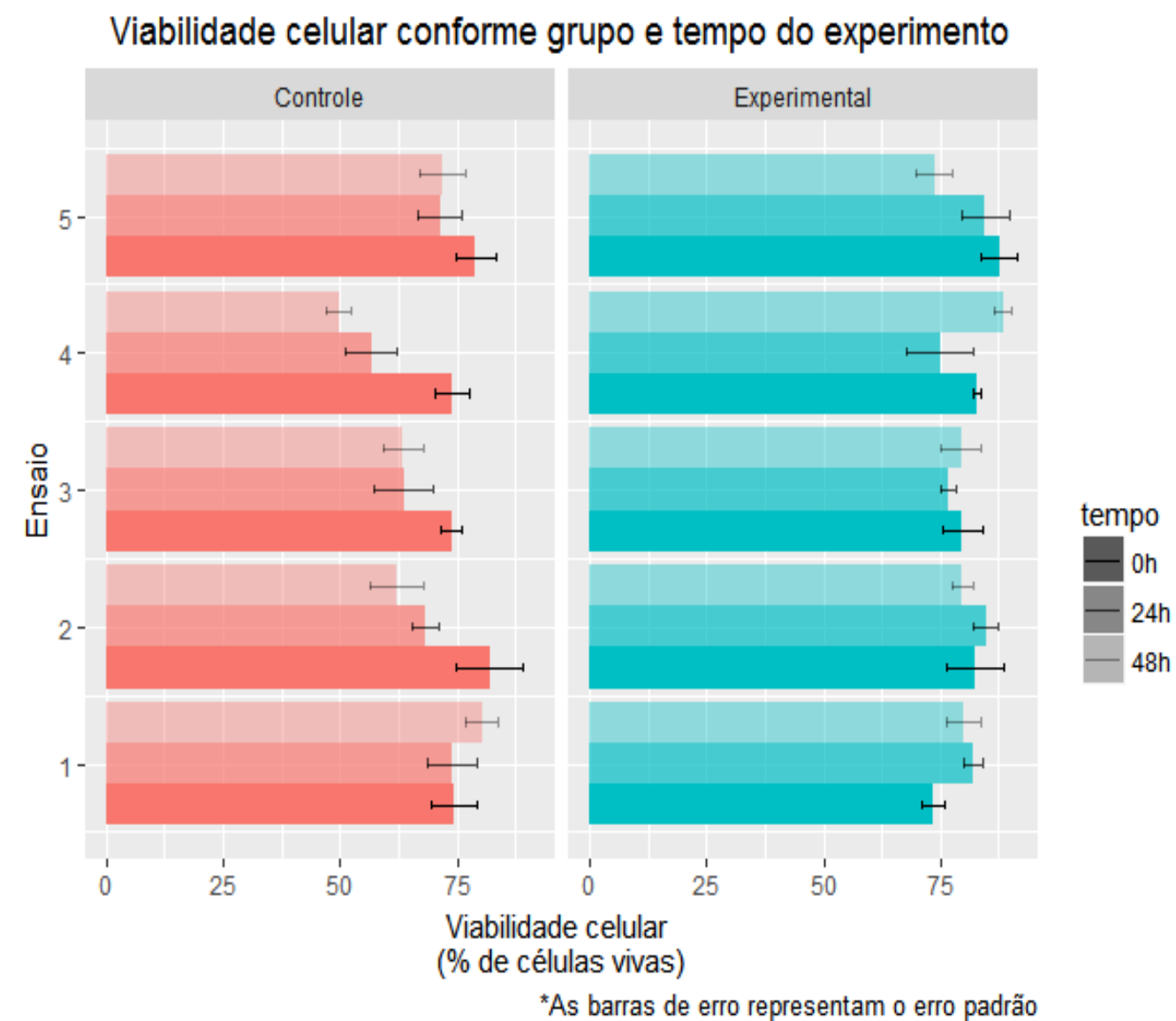

Ao se observar a média dos cinco ensaios para cada momento da aferição segundo o grupo estudado, observou-se que para T0h, T24h e T48h as médias da viabilidade celular foram superiores no grupo experimental (Tabela 5.2). 
Tabela 5.2 - Descrição da viabilidade celular média, dada porcentagem de células vivas, nos grupos controle e experimental conforme a aferição em cada momento diferente do tempo - 0 h, $24 \mathrm{~h}$ e $48 \mathrm{~h}$ do ensaio. São Paulo, 2017.

\begin{tabular}{lcccccc}
\hline \multirow{2}{*}{ Parâmetros } & \multicolumn{3}{c}{ Controle } & \multicolumn{3}{c}{ Experimental } \\
\cline { 2 - 7 } & Oh & $\mathbf{2 4 h}$ & $\mathbf{4 8 h}$ & Oh & $\mathbf{2 4 h}$ & $\mathbf{4 8 h}$ \\
\hline Média & 76,61 & 66,74 & 65,54 & 81,20 & 80,54 & 80,24 \\
Desvio Padrão & 3,64 & 6,80 & 11,46 & 5,18 & 4,55 & 5,28 \\
Erro Padrão & 1,63 & 3,04 & 5,12 & 2,32 & 2,04 & 2,36 \\
Mediana & 74,44 & 68,23 & 63,54 & 82,47 & 81,97 & 79,72 \\
Mínimo & 73,86 & 56,71 & 49,71 & 73,40 & 74,87 & 73,67 \\
Máximo & 81,93 & 73,88 & 80,41 & 87,53 & 84,80 & 88,43 \\
\hline
\end{tabular}

A representação gráfica da viabilidade celular média no grupo controle e experimental de acordo com o momento de aferição, permite visualizar a diferença entre os dois grupos (Gráfico 2).

Gráfico 2 - Viabilidade celular média, dada como porcentagem de células vivas, e seu respectivo erro padrão para os grupos controle e experimental para cada tempo aferido - 0h, 24h e 48h. São Paulo, 2017.

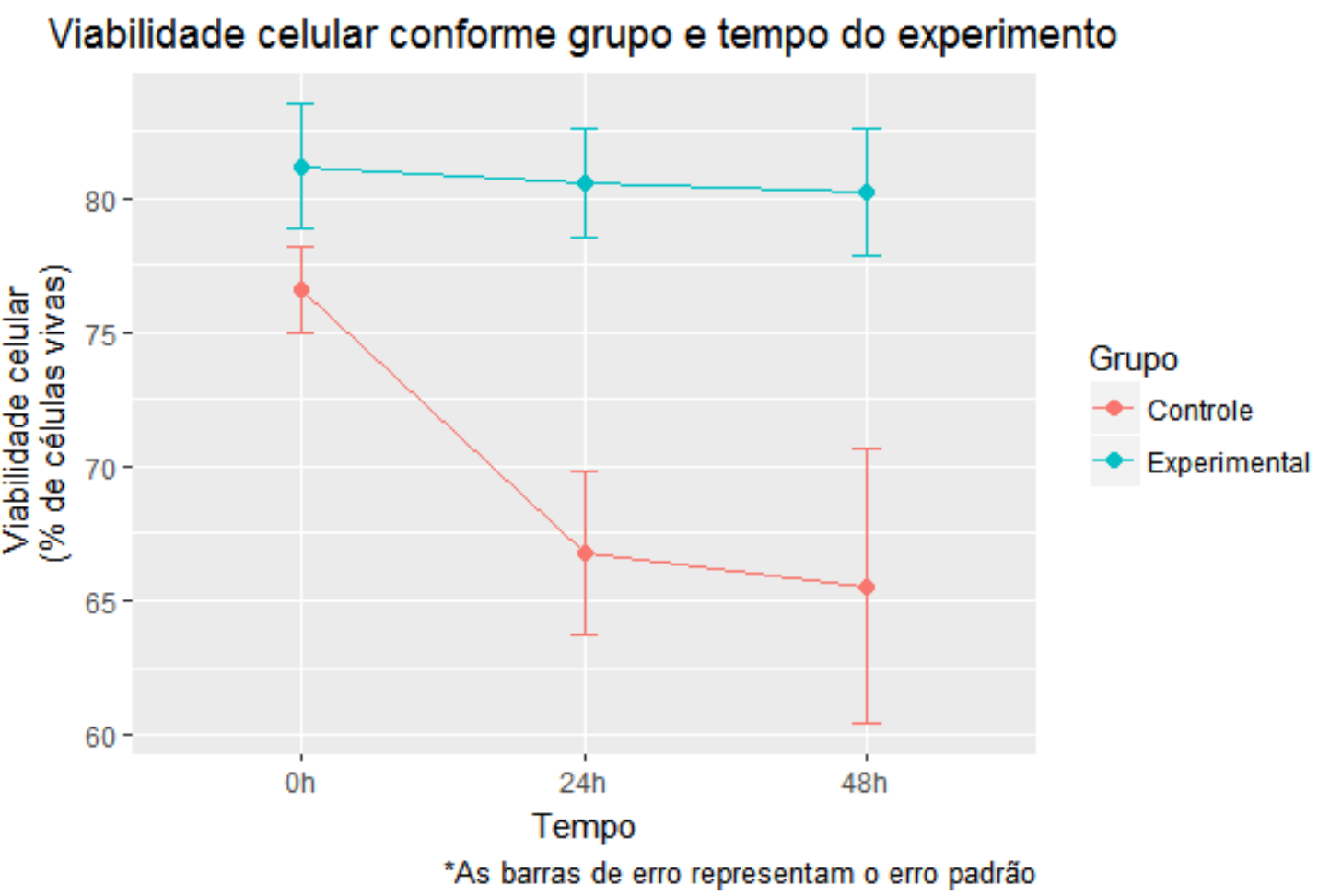


A viabilidade celular ao longo de $0 \mathrm{~h}, 24 \mathrm{~h}$ e $48 \mathrm{~h}$ nos grupo experimental e controle foi analisada por meio do modelo de equações de estimação generalizada (GEE), que mostrou diferença estatisticamente significativa entre os grupos, controle e experimental, ao longo do tempo $(p=0,0040)$, sendo maior a viabilidade celular no grupo experimental.

A atividade da MPO, expressa em Unidades Relativas de Luminescência, em duplicata, e a média entre ambas medidas foi considerada para análise estatística. As médias em cada ensaio foram superiores no grupo experimental, exceto no ensaio cinco. Além disso, no ensaio três do grupo experimental houve uma exacerbação da atividade da MPO (Gráfico 3).

Gráfico 3 - Atividade da mieloperoxidase, dada em Unidades Relativas de Luminescência (URL), em cada ensaio para os grupos controle e experimental. São Paulo, 2017.

\section{Atividade da mieloperoxidase de cada experimento conforme grupos controle e experimental}

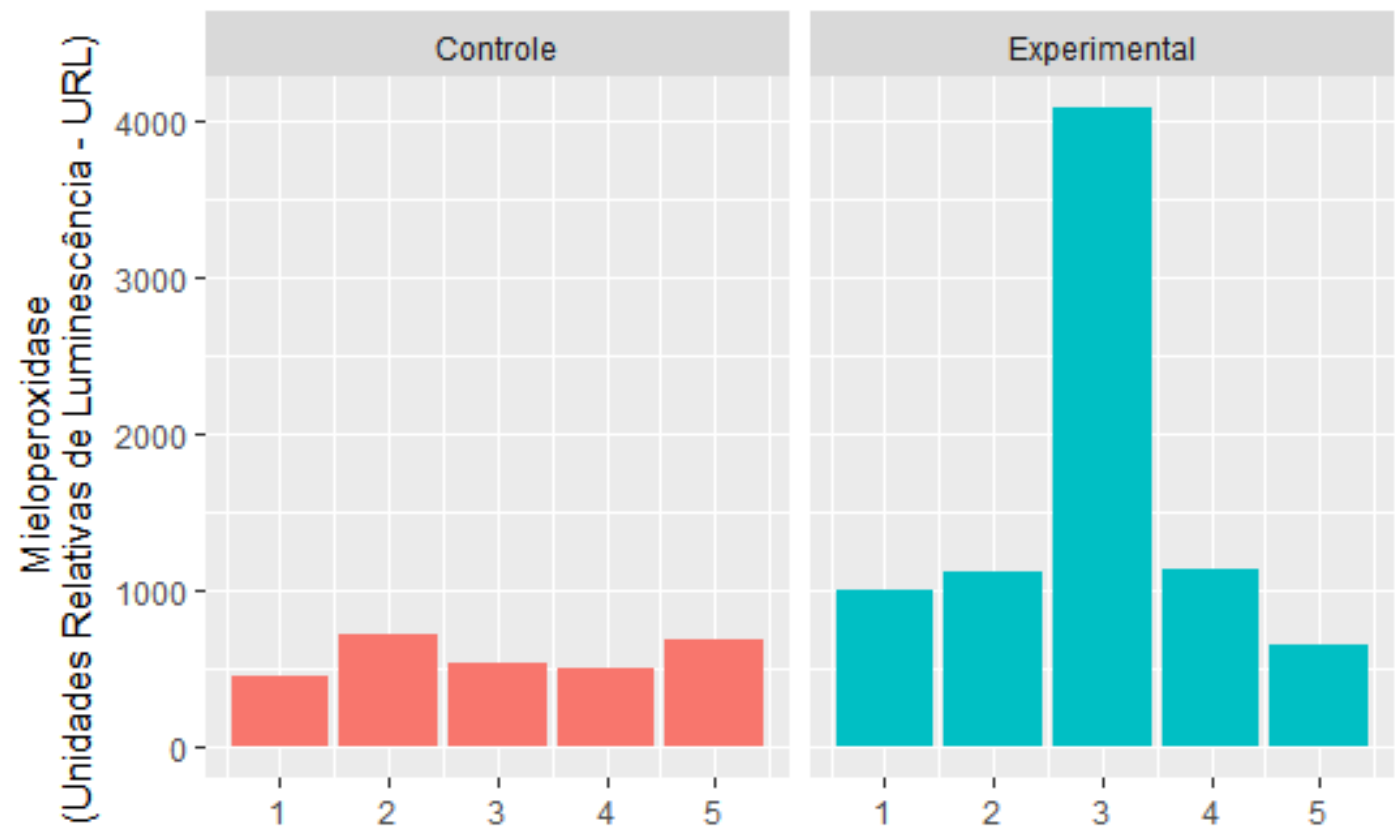

Experimentos 
A tabela 5.3 mostra uma diferença importante na média da atividade da MPO entre o grupo controle e experimental, provocada pelo valor médio da atividade da MPO no ensaio três do grupo experimental.

Tabela 5.3 - Descrição da atividade da mieloperoxidase, dada como Unidades Relativas de Luminescência (URL), nos grupos controle e experimental. São Paulo, 2017.

\begin{tabular}{lcc}
\hline \multicolumn{1}{c}{ Parâmetros } & Controle & Experimental \\
\hline Média & 574,20 & 1598,00 \\
Desvio Padrão & 113,30 & 1331,60 \\
Erro Padrão & 51,57 & 627,03 \\
Mediana & 537,50 & 1096,00 \\
Mínimo & 431,00 & 612,00 \\
Máximo & 754,00 & 4411,00 \\
\hline
\end{tabular}

O gráfico 4 permite uma visualização espacial das médias descritas na tabela 5.3. 
Gráfico 4 - Atividade da mieloperoxidase, dada em Unidades Relativas de Luminescência, e seu respectivo erro padrão para os grupos controle e experimental. São Paulo, 2017.

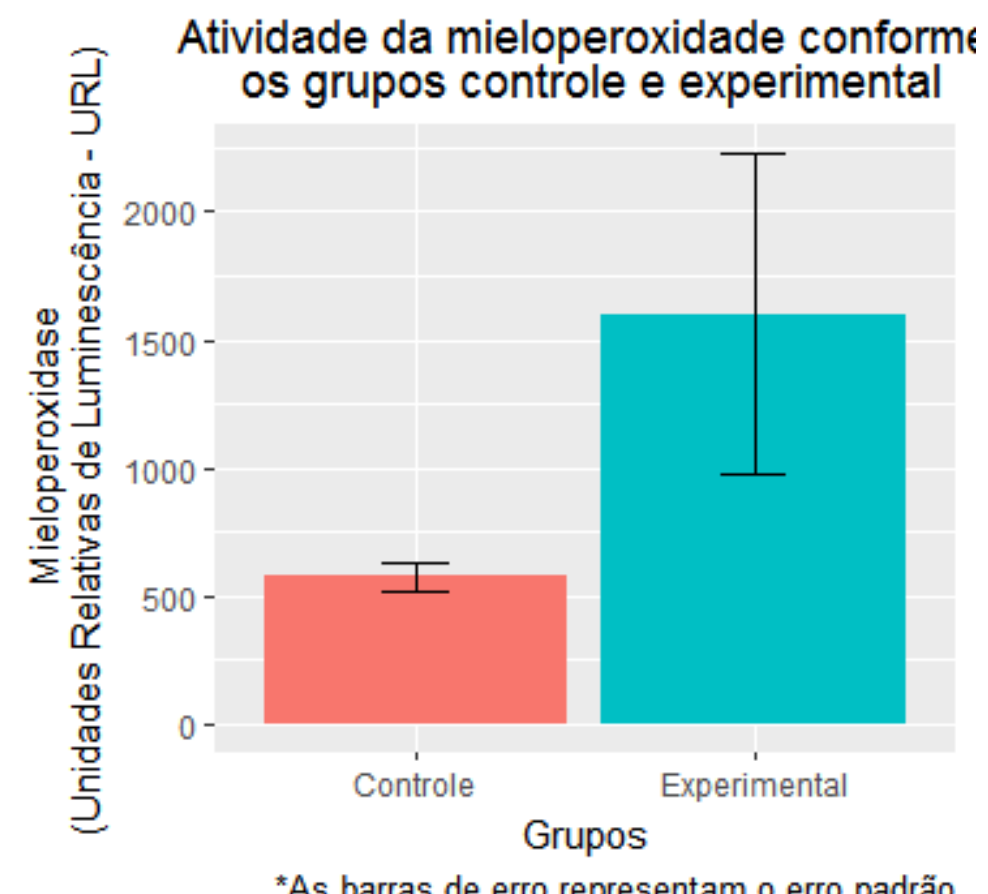

A atividade da mieloperoxidase entre os grupos controle e experimental foi analisada pelo teste de ANOVA para medidas repetidas não paramétrico, encontrando-se diferença estatisticamente significante entre os grupos $(p=0,002)$, sendo verificada maior atividade no grupo experimental. 
6 DISCUSSÃO 


\section{DISCUSSÃO}

A imunidade inata é responsável pela primeira resposta do corpo aos agentes lesivos e coordena a ação da resposta imune adaptativa. Sua importância intrínseca na sobrevivência do indivíduo foi um dos motivos escolhidos para a realização do ensaio com neutrófilos. Além disso, a possibilidade de avaliar os efeitos do Reiki in vitro, em condições experimentais controláveis e replicáveis, assim como pelo duplo cegamento estabelecido, possibilitou entender os resultados em dois níveis: (i) como o Reiki, como terapia de biocampo, consegue agir sobre um conjunto celular isolado, e (ii) como essas células se comportaram em termos de sobrevivência (viabilidade celular) e expressão das suas respostas fisiológicas normais a um estímulo (liberação de mieloperoxidase).

O duplo cegamento, tanto do praticante da técnica (pesquisador), quanto do estatístico responsável pela análise dos dados, buscou diminuir vieses na intervenção e na análise dos dados. Utilizou-se uma triplicata instrumental para a análise da viabilidade celular e uma duplicata na verificação da atividade da enzima mieloperoxidase (MPO), a fim de reduzir a possibilidade de erros de mensuração que afetassem os resultados.

Os ensaios realizados demonstraram, com diferença estatisticamente significativa, que houve maior viabilidade celular e maior liberação da enzima mieloperoxidase no grupo tratado com Reiki em relação ao grupo controle.

Sugere-se que estudos posteriores abranjam demais pontos dos critérios de causalidade propostos por Doll e Hill (1965) (Fernando et al., 2014), como gradiente biológico (relação dose-resposta) e consistência (estudos similares que corroborem com os resultados encontrados). E desta forma, haja consenso sobre a modulação do Reiki sobre a viabilidade e atividade da mieloperoxidase em neutrófilos in vitro.

O Reiki é o fluxo da energia vital universal, que passa através do praticante, equilibrando e fortalecendo a energia de quem a recebe (Miles e True, 2003). Esta energia visa o equilíbrio do organismo, de acordo com suas próprias necessidades, na tentativa do alcance da sua homeostase. Dessa forma, diversos estudos têm 
demonstrado sua ação: diminuição da pressão arterial (Salles et al., 2014), relaxamento, diminuição da dor e melhoria no sistema imune.

Vendegodt et al., (2003) discorrem sobre a hipótese holística da cura. Segundo os autores, a cura ocorre em um "estado de consciência em um alto nível de energia" e que neste processo há três estados obrigatórios: o sentido, o entender e o deixar passar decisões negativas. Este processo ocorre dependente de uma série de fatores, que podem ser sintetizadas como um ambiente seguro, e o desejo de viver, a confiança, a intenção de cura e boas perspectivas de vida tanto do paciente quanto do médico. Algumas terapias complementares são citadas pelos autores como métodos que levam ao processo holístico de cura (Ventegodt et al., 2003). O Reiki, como terapia complementar também visa atingir o equilíbrio energético do corpo como um todo, visando um completo bem-estar, promovendo na dinâmica corpo-emoçãomente-espírito, um alinhamento da energia (Salles e Silva, 2011).

Neste contexto, a energia vital, canalizada durante a aplicação do Reiki pelo terapeuta, necessitaria de um corpo como sistema completo, com os canais tradicionais de energia para que houvesse uma ação efetiva, promovendo o equilíbrio. Entretanto, no presente estudo observou-se efeitos diretos da terapia Reiki sobre uma população celular isolada, o que rompe com a ideia tradicional da energia atuando sobre um corpo holístico e consciente, permitindo novas perspectivas sobre a ação do Reiki.

A teoria holográfica citada por Wilber et al (2002 p.109-10), na qual propõe, entre outros, que o holos é a parte que representa o todo, foi considerada para fins deste estudo, na avaliação dos efeitos do Reiki sobre células isoladas, a fim de que se verificasse, por meio dos parâmetros de avaliação escolhidos, se haveria ou não efeitos sobre a sobrevida e atividades fisiológicas de neutrófilos humanos in vitro.

Desta forma, compreendeu-se o neutrófilo como uma célula passível de receber a energia disponibilizada pela terapia Reiki e sensível as ações por ela provocadas. $O$ aumento da viabilidade celular e da liberação de mieloperoxidase são indicativos que a ação sensível do Reiki sobre os neutrófilos está no alcance de sua homeostase celular, resultando em maior viabilidade destes em relação ao grupo controle, e maior expressão de sua atividade fisiológica, indicada pelo aumento da liberação de mieloperoxidase presente nos grânulos azurofílicos. 
O biocampo, conforme definido pela US National Institutes of Health Conference de 1992, é definido como um "campo sem massa, não necessariamente eletromagnético, que envolve e permeia corpos vivos e afeta o corpo" (Jain et al., 2015). Embora haja estudos que demonstram a efetividade de variadas técnicas de biocampo, ainda não há uma explicação biológica suficientemente elucidada e estudos não compreendem o rigor metodológico necessário. Os modelos in vitro, neste sentido, permitem maior controle das variáveis experimentais, são possíveis de serem replicados por outros pesquisadores e obtém resultados pontuais que possibilitam, por meio de marcadores determinados, entender as ações da terapia sobre a "parte" (célula), e repensar novas possibilidades para investigar seu mecanismo de ação para o "todo" (indivíduo).

Pela limitação de estudos na literatura que avaliam a ação do Reiki sobre células do sistema imune in vitro, os resultados obtidos no presente estudo necessitam ser compreendidos considerando resultados de estudos que utilizam outras técnicas de biocampo e que, muitas vezes, são avaliações in vivo.

Em ensaios clínicos com terapias de biocampo, em geral, os autores buscam compreender os efeitos sobre a viabilidade e atividade de células NK, linfócitos e imunoglobulinas. Lutgendorf et al., (2010), em estudo clínico randomizado, avaliou o efeito do Toque Terapêutico sobre o humor, qualidade de vida e imunidade celular de 60 mulheres com câncer cervical em tratamento com quimiorradiação. Comparou-se o grupo tratado com toque terapêutico em relação a um grupo treinado em técnicas de relaxamento e outro que recebeu apenas os cuidados convencionais. Observouse que os pacientes tratados com toque terapêutico tiveram níveis de atividade das células NK maior que dos demais grupos, embora a quantidade celular tenha sido reduzida em todos os grupos e não houve diferença entre os grupos em relação a toxidade, contagem leucocitária, eritrocitária, fadiga e qualidade de vida (Lutgendorf et al., 2010). Oliveira (2003) também observou aumento da atividade citotóxica das células NK e dos linfócitos LAK no grupo de camundongos em que aplicaram Toque Terapêutico.

Wardell e Engebreston (2001), por sua vez, observaram que após aplicação de 30 minutos de Reiki em indivíduos saudáveis, havia uma redução significativa nos níveis de ansiedade, diminuição da pressão sanguínea e dos padrões eletromiográficos e um aumento nos níveis de imunoglobulina A salivar. 
Lee et al. (2001) demonstraram o efeito do Qi-training, modalidade coreana do Qiqong, em que a técnica procura proteger e fortalecer o corpo do praticante e do paciente, e, também, prevenir e curar doenças. Neste estudo, feito com 31 voluntários, os pesquisadores procuraram avaliar os efeitos psicológicos (índices provindos de questionários validados para aferição do humor), imunes (células NK e neutrófilos) e endócrinos (cortisol e melatonina) da aplicação da técnica em relação a um grupo placebo. O grupo tratado apresentou melhora no humor, diminuição da ansiedade, diminuição dos níveis de cortisol. Observou-se também um aumento, ao longo do tempo, nos níveis de melatonina no grupo controle e queda no grupo placebo. $\mathrm{Na}$ avaliação do sistema imunológico, houve diferença estatisticamente significativa na geração de superóxidos entre os grupos ao longo do tempo. Os autores discutem que os reflexos no sistema imunológico devem ser decorrentes da diminuição dos níveis de cortisol, amenizando o seu efeito imunossupressor, e o aumento dos níveis de melatonina (Lee et al., 2001). Alguns estudos têm demonstrado que o aumento dos níveis de melatonina está diretamente relacionado à melhoria do sistema imune, explicando os resultados sobre as células NK e os neutrófilos.

Fernandes, Nóbrega e Tosta (2012) encontraram, pela meditação prânica, uma maior capacidade fagocitária e aumento na concentração de peróxido de hidrogênio produzido pelos neutrófilos e monócitos e uma redução dos níveis de corticotrofina.

O que, nos estudos de Ludgendorf et al., (2010), Wardell e Engebreston (2001) e Oliveira (2003) não fica claro, mas que no estudo de Lee (2001) torna-se evidente, é a proposta que as terapias de biocampo atuam na imunidade de forma indireta. Sejam os benefícios, a melhor atividade das células NK e dos neutrófilos, ou a maior expressão de imunoglobulinas, todos são decorrentes da estimulação da liberação de glicocorticoides pela indução do eixo hipotálamo-hipófise-adrenal ou do eixo simpático-adrenal-medular (Goldrosen e Straus, 2004).

Estudos in vitro, como o ensaio desta pesquisa, demonstraram que há, também, uma ação direta da aplicação da terapia Reiki sobre a célula isolada. É claro, que em um organismo multicelular e complexo, a ação sobre o sistema imune deve ser mediada tanto pela ação no sistema endócrino e neurológico quanto de forma direta sobre as populações celulares. 
Pesquisas demonstraram que as terapias de biocampo aplicadas sobre cultivos celulares apresentam respostas diferentes conforme as células alvo. Em células cancerígenas, por exemplo, como avaliado por Shah et al. (1999), constatou-se uma inibição da proliferação celular, tanto através da técnica de Yuanjii, em que foi observada uma inibição da proliferação de células MCF-7 (câncer de mama), K562 (leucemia), MEL6 (melanoma com knockout para p53) e LNaP (câncer de próstata), quanto através da aplicação do Toque Terapêutico, conforme o estudo de Gronowicz et al. (2011), sobre células U87 de glioblastoma humano. Muitos estudos, entretanto, foram inconclusivos, como os de Taft et al. (2005), Hall et al. (2007) e Young et al., (2013).

Em células normais, no entanto, observou-se o aumento da proliferação celular, como visto por Gronowicz et al. (2008) em relação a osteoblastos, tenócitos e fibroblastos que haviam recebido sessões de Toque Terapêutico. Do mesmo modo, o presente estudo observou aumento da viabilidade celular dos neutrófilos que receberam aplicação de Reiki em relação ao grupo controle. Alguns autores procuraram entender os mecanismos de ação da terapia de biocampo que estaria agindo sobre a célula. Kiang (2005), verificou que as técnicas de biocampo aumentam a concentração intracelular de cálcio por mediarem a troca de íons de sódio e cálcio em canais voltagem-dependentes.

Assim, estes dados da literatura, sugerem que as terapias de biocampo teriam uma ação direcionada e capaz de detectar o real estado celular para destiná-lo a um desfecho fisiologicamente programado. No caso de células normais, espera-se que sua maior ação seja a sobrevivência celular que, dependendo da célula em questão, pode ocorrer maior viabilidade no meio quanto maior proliferação de sua população. Em células cancerígenas, por terem mecanismos alterados na regulação da sua proliferação e metabolismo, houve proliferação inibida pelas terapias de biocampo.

De acordo com os resultados da presente pesquisa foi possível constatar os efeitos da terapia Reiki sobre os dois parâmetros de mensuração propostos para avaliar as células neutrofílicas humanas in vitro, provenientes de voluntários saudáveis. Efetivamente, aquelas que receberam a terapia Reiki, em relação às que não receberam, apresentaram níveis significativos na liberação de mieloperoxidase, o que denota uma possível melhora na performance de uma das atividades fisiológicas expressas por esse tipo de célula, assim como sugere, também, um melhor equilíbrio 
da manutenção das funções vitais celular no grupo experimental, por meio de uma maior preservação da viabilidade dos neutrófilos do que no grupo controle. Tais achados corroboram, conforme citado por Milles e True (2003), que o Reiki atua como uma via da energia universal para proporcionar equilíbrio e fortalecimento da energia.

Embora o estudo in vitro permita melhor controle de vieses, estudos de biocampo estabelecem uma ressonância com o campo vibracional do praticante da terapia e do ambiente onde se realiza a intervenção. A contagem de células depende do observador e o ideal seria ter a leitura realizada por dois observadores, para se avaliar a concordância dos resultados obtidos. Não há estudos que apresentem informações sobre a expansão do biocampo após tratamento, assim não se sabe se o biocampo do grupo experimental interferiu com as placas de cultivo do grupo controle, pois ambos permaneceram na mesma incubadora.

Não foi possível compreender a expressão exacerbada da MPO no terceiro ensaio do grupo experimental, porém, esta pode estar relacionada a diferentes fatores, como alguma característica específica do voluntário que fez a doação de sangue, ou então algo pertinente ao praticante de Reiki, ou ainda a influência de algum estímulo externo, que não foi identificado durante o experimento. 
7 CONCLUSÃO 


\section{CONCLUSÃo}

De acordo com os resultados da presente pesquisa foi possível constatar os efeitos da terapia Reiki sobre os dois parâmetros de mensuração propostos para avaliar as células neutrofílicas humanas in vitro, provenientes de voluntários saudáveis. O presente estudo demonstrou, com diferença estatisticamente significante, que houve:

- Maior viabilidade dos neutrófilos ao longo do tempo (de 0 h, 24 h e 48 h) quando receberam o Reiki durante $15 \mathrm{~min}$, a $15 \mathrm{~cm}$ de distância a cada 24horas.

- Maior liberação da enzima mieloperoxidase, aferida pelo ensaio de quimiluminescência, pelos neutrófilos que receberam uma sessão de Reiki.

Os resultados permitem apresentar algumas hipóteses a serem testadas como: (1) A maior sobrevivência celular do neutrófilo in vitro e melhor atividade da enzima MPO dessas células permite benefícios da terapia Reiki em indivíduos debilitados imunologicamente, quando associada aos tratamentos convencionais. (2) A homeostase da energia vital pelo Reiki favorece a migração de neutrófilos até os tecidos na presença de um agente agressor. (3) O Reiki permite maior liberação da MPO, que tem ação microbicida.

O presente estudo demonstra a necessidade da realização de mais estudos com neutrófilos humanos in vitro, submetidos à aplicação da técnica Reiki, para avaliar a reprodutibilidade deste estudo e também verificar se com a presença de dois observadores na contagem das células, os resultados seriam semelhantes. 
8 REFERÊNCIAS 


\section{REFERÊNCIAS}

Abbas AK, Lichtman AH. Imunologia básica: funções e distúrbios do sistema imunológico. $3^{\circ}$ ed. Rio de Janeiro: Elsevier; 2009.

Abdalla E. Teoria quântica da gravitação: cordas e teoria M. Rev Bras Ensino Física 2005;27:147-55.

Achterberg J, Cooke K, Richards T, Standish LJ, Kozak L, Lake J. Evidence for correlations between distant intentionality and brain function in recipients: a functional magnetic resonance imaging analysis. J Altern Complement Med 2005;11:965-71.

Assefi N, Bogart A, Goldberg J, Buchwald D. Reiki for the Treatment of Fibromyalgia: A Randomized Controlled Trial. J Altern Complement Med 2008;14:1115-22.

Böyum A. Separation of leukocytes from blood and bone marrow. Introduction. Scand J Clin Lab Invest Suppl 1968;97:7.

Capra F. O ponto de mutação. São Paulo: Cultrix; 1982.

Carvalho WA, Lemônica L. Mecanismos celulares e moleculares da dor inflamatória: modulaçäo periférica e avanços terapêuticos. Rev bras anestesiol 1998;48:137-58.

Crawford SE, Leaver VW, Mahoney SD. Using Reiki to Decrease Memory and Behavior Problems in Mild Cognitive Impairment and Mild Alzheimer's Disease. J Altern Complement Med 2006;12:911-3.

Cristovam MA da S, Gonçalves GF, Takemura OS, Tomasini API, Dragunski D, Reolon $\mathrm{J}$, et al. Degranulation of neutrophils ex-vivo by the action of polymer cassava's starch. Ciênc Rural 2010;40:1103-8.

Cruvinel W de M, Mesquita Júnior D, Araújo JAP, Catelan TTT, Souza AWS de, Silva NP da, et al. Immune system: Part I. Fundamentals of innate immunity with emphasis on molecular and cellular mechanisms of inflammatory response. Rev Bras Reumatol 2010;50:434-47.

De’ Carli J. Reiki Universal. São Paulo: Madras; 2001.

Diaz-Rodriguez L, Arroyo-Morales M, Fernandez-de-las-Penas C, Garcia-Lafuente F, Garcia-Royo C, Tomas-Rojas I. Immediate Effects of Reiki on Heart Rate Variability, 
Cortisol Levels, and Body Temperature in Health Care Professionals With Burnout. Biol Res Nurs 2011;13:376-82.

Fernandes CA, Nóbrega YKM, Tosta CE. Pranic meditation affects phagocyte functions and hormonal levels of recent practitioners. J Altern Complement Med 2012;18:761-8.

Fernando L, De Araújo C, Dalgalarrondo P, Banzato CEM. Sobre a noção de causalidade na medicina: aproximando Austin Bradford Hill e John L. Mackie. Rev Psiq Clín 2014;41:56-61.

Forbes MA, Rust R, Becker GJ. Surface electromyography apparatus as a measurement device for biofield research: results from a single case study. J Altern Complement Med 2004;10:617-26.

Garé RR. Efeitos do reiki na evolução do granuloma induzido através da inoculação do BCG em hamsters e do tumor ascítico de Ehrlich induzido em camundongos. São Paulo: Faculdade de Medicina Veterinária e Zootecnia, Universidade de São Paulo; 2008.

Goldrosen MH, Straus SE. Complementary and alternative medicine: assessing the evidence for immunological benefits. Nat Rev Immunol 2004;4:912-21.

Gronowicz G. Therapeutic Touch and Cancer Cells. UCHC Grad Sch Masters Theses 2003 - $20102011: 167$.

Gronowicz GA, Jhaveri A, Clarke LW, Aronow MS, Smith TH. Therapeutic touch stimulates the proliferation of human cells in culture. $J$ Altern Complement Med 2008;14:233-9.

Hall Z, Luu T, Moore D, Yount G. Radiation response of cultured human cells is unaffected by Johrei. Evid Based Complement Altern Med 2007;4:191-4.

Hatanaka E, Levada-Pires AC, Pithon-Curi TC, Curi R. Systematic study on ROS production induced by oleic, linoleic, and $\mathrm{y}$-linolenic acids in human and rat neutrophils. Free Radic Biol Med 2006;41:1124-32.

Jain S, Hammerschlag R, Mills P, Cohen L, Krieger R, Vieten C, et al. Clinical Studies of Biofield Therapies: Summary, Methodological Challenges, and Recommendations. Glob Adv Heal Med 2015;4:58-66. 
Junqueira L., Carneiro J. Histologia básica. $11^{\circ}$ ed. Rio de Janeiro: Guanabara Koogan; 2011.

Kaplan MJ, Radic M. Neutrophil Extracellular Traps: Double-Edged Swords of Innate Immunity. J Immunol 2012;189:2689-95.

Kiang JG, Ives JA, Jonas WB. External bioenergy-induced increases in intracellular free calcium concentrations are mediated by $\mathrm{Na}+/ \mathrm{Ca} 2+$ exchanger and L-type calcium channel. Mol Cell Biochem 2005;271:51-9.

Kolaczkowska E, Kubes P. Neutrophil recruitment and function in health and inflammation. Nat Rev Immunol 2013;13:159-75.

Lee MS, Huh HJ, Hong S-S, Jang $H-S$, Ryu $H$, Lee $H-S$, et al. Psychoneuroimmunological effects of Qi-therapy: preliminary study on the changes of level of anxiety, mood, cortisol and melatonin and cellular function of neutrophil and natural killer cells. Stress Heal 2001;17:17-24.

Lucchetti G, de Oliveira RF, Gonçalves JP de B, Ueda SMY, Mimica LMJ, Lucchetti ALG. Effect of Spiritist "passe" (Spiritual healing) on growth of bacterial cultures. Complement Ther Med 2013;21:627-32.

Lutgendorf SK, Mullen-Houser E, Russell D, Degeest K, Jacobson G, Hart L, et al. Preservation of immune function in cervical cancer patients during chemoradiation using a novel integrative approach. Brain Behav Immun 2010;24:1231-40.

Mager J, Moore D, Bendl D, Wong B, Rachlin K, Yount G. Evaluating biofield treatments in a cell culture model of oxidative stress. Explor 2007;3:386-90.

Midilli TS, Eser I. Effects of Reiki on Post-cesarean Delivery Pain, Anxiety, and Hemodynamic Parameters: A Randomized, Controlled Clinical Trial. Pain Manag Nurs 2015;16:388-99.

Miles P, True G. Reiki--review of a biofield therapy history, theory, practice, and research. Altern Ther Health Med 2003;9:62-72.

Montanari T. Histologia: texto, atlas e roteiro de aulas práticas. Porto Alegre: Ed. do autor; 2013.

Morandi AC, Molina N, Guerra BA, Bolin AP, Otton R. Fucoxanthin in association with 
vitamin C acts as modulators of human neutrophil function. Eur J Nutr 2014;53:779_ 92.

Morse ML, Beem LW. Case Reports Benefits of Reiki Therapy for a Severely Neutropenic Patient with Associated Influences on a True Random. J Altern Complement Med 2011;17:1181-90.

Motta PMR da. Aplicação das técnicas de imposição de mãos no câncer, dor e stressansiedade: revisão sistemática da literatura. Campinhas: Faculdade de Ciências Médicas, Universidade Estadual de Campinas; 2014.

Movaffaghi Z, Farsi M. Biofield therapies: biophysical basis and biological regulations? Complement Ther Clin Pr 2009;15:35-7.

NCCIH. National Center for Complementary and Integrative Health (NCCIH) 2015. [citado 2016 abr. 4]. Disponível em: https://nccih.nih.gov/.

Odobasic D, Kitching AR, Holdsworth SR. Neutrophil-Mediated Regulation of Innate and Adaptive Immunity: The Role of Myeloperoxidase. J Immunol Res 2016;2016.

Oliveira RMJ de. Avaliação de efeitos da prática de impostação de mãos sobre os sistemas hematológico e imunológico de camundongos machos. São Paulo: Faculdade de Medicina, Universidade de São Paulo; 2003.

Peres CM, Curi R. Como Cultivar Células. $1^{\circ}$ ed. Rio de Janeiro: Editora Guanabara Koogan; 2005.

Perez-Reyes E. Molecular physiology of low-voltage-activated t-type calcium channels. Physiol Rev 2003;83:117-61.

Rang H., Dale M., Ritter J., Flower R. RANG \& DALE Farmacologia. $6^{\circ}$ ed. Rio de Janeiro: Elsevier; 2007.

Rindfleisch JA. Biofield therapies: energy medicine and primary care. Prim care 2010;37:165-79.

Rosch PJ. Bioelectromagnetic and subtle energy medicine: the interface between mind and matter. Ann N Y Acad Sci 2009;1172:297-311.

Rubik B, Brooks AJ, Schwartz GE. In vitro effect of Reiki treatment on bacterial cultures: Role of experimental context and practitioner well-being. J Altern 
Complement Med 2006;12:7-13.

Salles LF, Silva MJP da. Enfermagem e as práticas complementares em saúde. São Caetano do Sul: Yendis Editora; 2011.

Salles LF, Vannucci L, Salles A, Silva MJP da. The effect of Reiki on blood hypertension. Acta paul enferm 2014;27:479-84.

Santos KC dos. Análise proteômica comparativa entre neutrófilos não ativados e ativados com PMA, um análogo do diacilglicerol. Brasília: Instituto de Ciências Biomédicas; 2007.

Shah S, Ogden AT, Pettker CM, Raffo A, Itescu S, Oz MC. A Study of the Effect of Energy Healing on In Vitro Tumor Cell Proliferation. J Altern Complement Med 1999;5:359-65.

Shao L, Zhang J, Chen L, Zhang X, Chen KW. Effects of External Qi of Qigong with Opposing Intentions on Proliferation of Escherichia coli. J Altern Complement Med 2009;15:567-71.

Sousa IMC de, Bodstein RC de A, Tesser CD, Santos F de A da S, Hortale VA. Integrative and complementary health practices: the supply and production of care in the Unified National Health System and in selected municipalities in Brazil. Cad Saude Publica 2012;28:2143-54.

Taft R, Moore D, Yount G. Time-lapse analysis of potential cellular responsiveness to Johrei, a Japanese healing technique. BMC Complement Altern Med 2005;5:2.

Taft R, Nieto L, Pennucci A, Moore D, Yount G. Cultured human brain tumor cells do not respond to Johrei treatment. Subtle Energies Energy Med J Arch 2003;14:253-65.

Thieblemont N, Wright HL, Edwards SW, Witko-Sarsat V. Human neutrophils in autoimmunity. Semin Immunol 2016;28:159-73.

Tsang KL, Carlson LE, Olson K. Pilot Crossover Trial of Reiki Versus Rest for Treating Cancer-Related Fatigue. Integr Cancer Ther 2007;6:25-35.

Ventegodt S, Andersen NJ, Merrick J. Holistic Medicine III: The Holistic Process Theory of Healing. ScientificWorldJournal 2003;3:1138-46.

Warber SL, Cornelio D, Straughn J, Kile G. Biofield energy healing from the inside. J 
Altern Complement Med 2004;10:1107-13.

Wardell DW, Engebretson J. Biological correlates of Reiki Touchsm healing. J Adv Nurs $2001 ; 33: 439-45$.

Wilber K. A União da alma e dos sentidos: integrando ciência e religião. São Paulo: Cultrix; 2002.

Wirth DP, Brenlan DR, Levine RJ, Rodriguez CM. The effect of complementary healing therapy on postoperative pain after surgical removal of impacted third molar teeth. Complement Ther Med 1993;1:133-8.

Yount G, Patil S, Dave U, Alves-dos-Santos L, Gon K, Arauz R, et al. Evaluation of biofield treatment dose and distance in a model of cancer cell death. $\mathrm{J}$ Altern Complement Med 2013;19:124-7.

Yount G, Smith S, Avanozian V, West J, Moore D, Freinkel A. Biofield perception: a series of pilot studies with cultured human cells. J Altern Complement Med 2004;10:463-7. 


\section{GLOSSÁRIO}

Johrei Técnica de tratamento, proveniente do Japão, que canaliza energia cósmica. É aplicada através da imposição de mãos, que de acordo com os praticantes, promove aumento da capacidade de recuperação natural que o ser humano possui.

LeShan Técnica de meditação desenvolvida pelo psicólogo Lawrence LeShan.

Meditação Visa atuar no restabelecimento do equilíbrio de todas as prânica dimensões do indivíduo, tanto na dimensão social, quanto na espiritual, emocional, mental ou física. Fundamenta-se no princípio de que doenças são geradas por desequilíbrios em quaisquer níveis das dimensões citadas, tendo como base a Medicina Ayurvédica.

Qi Gong Exercícios tradicionais de respiração, provenientes da medicina tradicional Chinesa, praticados com o intuito de melhorar a imunidade pela eliminação de toxinas, por meio da coordenação da respiração, da mente e do corpo.

Toque É um tipo antigo de terapia vibracional, aplicada por imposição de Terapêutico mãos, a fim de reequilibrar a energia. Está fundamentada na capacidade humana de promover o equilíbrio da energia vital, a fim de que o seu desequilíbrio não venha contribuir com o aparecimento de doenças. Na Enfermagem, em 1972, houve o desenvolvimento e sistematização desta terapêutica complementar pela enfermeira Dolores Krieger, objetivando contribuir na recuperação da saúde de pessoas doentes. 
Yuanji Combinação de dança, proveniente de Yuan-Ji Gong, com música Yuanji e técnicas como Tai-Chi, artes marciais, e outros, tornandose um tipo de exercício bastante popular entre os chineses, principalmente idosos. É uma associação de exercício físico, cuidados com a saúde, musculação e entretenimento. 


\section{APÊNDICE 1 - DADOS SÓCIODEMOGRÁFICOS}

- Nome:

- Idade sexo: FEM ( ) MASC ( ) Estado Civil

- Tem alguma doença de base? ( ) não ( ) sim

- $\quad$ Se sim, qual?

- Tem alergia? ( ) não ( ) sim. Qual

- Está com gripe?

- Tem outros problemas de saúde?

- É tabagista? ( ) não ( ) sim

- É etilista? ( ) não ( ) sim

- Faz uso de alguma droga ilícita? ( ) não ( ) sim

- Toma algum medicamento. Qual? Há quanto tempo?

- Tomou vacina recentemente? ( ) não ( ) sim

- Dormiu bem esta noite? ( ) não ( ) sim

- Está com alguma dor agora? ( ) não ( ) sim

- Faz uso de alguma terapia complementar no momento? Se sim, qual? 


\section{APÊNDICE 2 - TERMO DE CONSENTIMENTO LIVRE E ESCLARECIDO}

Estudo realizado pela mestranda Luciana Vannucci, supervisionada pela orientadora Prof. ${ }^{\text {a }}$ Dr. ㄹ Ruth Natália Teresa Turrini.

Você está sendo convidado a participar voluntariamente de um estudo que pretende avaliar o tempo de sobrevivência de um tipo de célula do sangue (neutrófilo) e sua função após aplicação de Reiki (técnica de imposição de mãos), e que neste estudo será aplicada sobre as suas células separadas do resto do sangue no laboratório. As células separadas serão colocadas em uma pequena placa de vidro com tampa e uma substância que serve para nutrir a célula e evitar que ela morra rápido. A pesquisa será desenvolvida no Laboratório de Fisiologia Celular e Biologia Molecular da Universidade Cruzeiro do Sul- Campus Anália Franco - São Paulo - SP.

Sua participação envolve responder a um questionário sobre dados demográficos e estado de saúde (uso de medicamentos, problemas de saúde e alergias) e permitir a coleta de $20 \mathrm{~mL}$ de sangue do seu braço por punção venosa periférica. Este sangue será utilizado para separar células (neutrófilos), que serão submetidas a aplicação de Reiki e, após o experimento o material será descartado (após $24 \mathrm{~h}$ ou 48 dependendo da sobrevivência das células).

A qualquer momento você terá direito de acessar as informações sobre o estudo ou se retirar da pesquisa. Sua identidade será mantida em sigilo, não só durante a pesquisa, mas também na publicação.

O estudo oferece risco mínimo, apenas desconforto pela dor da picada da agulha para a coleta de sangue. Os resultados poderão contribuir para melhorar o conhecimento científico sobre o efeito do Reiki sobre as células que estão sendo pesquisadas, uma maneira de comprovar o efeito do reiki sobre o bem-estar das pessoas.

Você não receberá nenhuma compensação financeira pela participação neste estudo, mas também não terá nenhum prejuízo financeiro. Haverá indenização caso haja comprovação ético legal de danos relacionados à coleta de dados.

O estudo atenderá à Resolução 466/2012 do Conselho Nacional de Saúde, ao envolver seres humanos na pesquisa. Dúvidas relacionadas aos aspectos éticos da pesquisa podem ser esclarecidos junto ao Comitê de Ética em Pesquisa da Escola de Enfermagem da USP, Av. Dr. Enéas de Carvalho Aguiar, 419, e-mail: cepee@usp.br, telefone: 30618858. Caso necessite, entrar em contato com o pesquisador: Luciana Vannucci - tel: (11) 966179135 ou Ruth Turrini - tel: (11) 30618842, Av. Dr Eneas de Carvalho Aguiar, 419 3o andar. 
Caso aceite participar, por favor, rubrique a página inicial e assine as duas vias deste Termo de Consentimento Livre e Esclarecido, sendo que uma delas ficará com você e a outra com a pesquisadora.

Data:

Pesquisador

Participante 


\title{
ANEXO 1 - Portaria no 971
}

\author{
PORTARIA № 971 DE 3 DE MAIO DE 2006.
}

Aprova a Política Nacional de Práticas Integrativas e Complementares (PNPIC) no Sistema Único de Saúde.

O MINISTRO DE ESTADO DA SAÚDE, INTERINO, no uso da atribuição que the confere o art. 87, parágrafo único, inciso II, da Constituição Federal, e Considerando o disposto no inciso II do art. 198 da Constituição Federal, que dispõe sobre a integralidade da atenção como diretriz do SUS; Considerando o parágrafo único do art. $3^{\circ}$ da Lei $n^{\circ}$ 8.080/90, que diz respeito às ações destinadas a garantir às pessoas e à coletividade condições de bem-estar físico, mental e social, como fatores determinantes e condicionantes da saúde; Considerando que a Organização Mundial da Saúde (OMS) vem estimulando o uso da Medicina Tradicional/Medicina Complementar/Alternativa nos sistemas de saúde de forma integrada às técnicas da medicina ocidental modernas e que em seu documento "Estratégia da OMS sobre Medicina Tradicional 2002-2005" preconiza o desenvolvimento de políticas observando os requisitos de segurança, eficácia, qualidade, uso racional e acesso; Considerando que o Ministério da Saúde entende que as Práticas Integrativas e Complementares compreendem o universo de abordagens denominado pela OMS de Medicina Tradicional e Complementar/Alternativa - MT/MCA; Considerando que a Acupuntura é uma tecnologia de intervenção em saúde, inserida na Medicina Tradicional Chinesa (MTC), sistema médico complexo, que aborda de modo integral e dinâmico o processo saúde-doença no ser humano, podendo ser usada isolada ou de forma integrada com outros recursos terapêuticos, e que a MTC também dispõe de práticas corporais complementares que se constituem em ações de promoção e recuperação da saúde e prevenção de doenças; Considerando que a Homeopatia é um sistema médico complexo de abordagem integral e dinâmica do processo saúde-doença, com ações no campo da prevenção de agravos, promoção e recuperação da saúde; Considerando que a Fitoterapia é um recurso terapêutico caracterizado pelo uso de plantas medicinais em suas diferentes formas farmacêuticas e que tal abordagem incentiva 0 desenvolvimento comunitário, a solidariedade e a participação social; Considerando que o Termalismo Social/Crenoterapia constituem uma abordagem reconhecida de indicação e uso de águas minerais de maneira complementar aos demais tratamentos de saúde e que nosso País dispõe de recursos naturais e humanos ideais ao seu desenvolvimento no Sistema Único de Saúde (SUS); e Considerando que a melhoria dos serviços, o aumento da resolutividade e o incremento de diferentes abordagens configuram, assim, prioridade do Ministério da Saúde, tornando disponíveis opções preventivas e terapêuticas aos usuários do SUS e, por conseguinte, aumentando o acesso, R E S O L V E: Art. 1ํ Aprovar, na forma do Anexo a esta Portaria, a Política Nacional de Práticas Integrativas e Complementares (PNPIC) no Sistema Único de Saúde. Parágrafo único. Esta Política, de caráter nacional, recomenda a adoção pelas Secretarias de Saúde dos Estados, do Distrito Federal e dos Municípios, da implantação e implementação das ações e serviços relativos às Práticas Integrativas e Complementares. Art. 2ํㅡㄹ Definir que os órgãos e entidades do Ministério da Saúde, cujas ações se relacionem com o tema da Política ora aprovada, devam promover a elaboração ou a readequação de seus planos, programas, projetos e atividades, na conformidade das diretrizes e responsabilidades nela estabelecidas. Art. $3^{\circ}$ Esta Portaria entra em vigor na data de sua publicação. JOSÉ AGENOR ÁLVARES DA SILVA 


\section{ANEXO 2 - Portaria no 849}

\section{PORTARIA № 849, DE 27 DE MARÇO DE 2017}

Inclui a Arteterapia, Ayurveda, Biodança, Dança Circular, Meditação, Musicoterapia, Naturopatia, Osteopatia, Quiropraxia, Reflexoterapia, Reiki, Shantala, Terapia Comunitária Integrativa e Yoga à Política Nacional de Práticas Integrativas e Complementares.

O MINISTRO DE ESTADO DA SAÚDE, no uso da atribuição que the confere o inciso II do parágrafo único do art. 87 da Constituição, e Considerando o disposto no inciso II do art. 198 da Constituição Federal, que dispõe sobre a integralidade da atenção como diretriz do SUS; Considerando a Lei ํo 8.080, de 19 de setembro de 1990, que dispõe sobre as condições para a promoção, proteção e recuperação da saúde, a organização e o funcionamento dos serviços correspondentes e dá outras providências; Considerando o Decreto $n^{\circ} \mathbf{7 . 5 0 8}$, de 28 de junho de 2011, que regulamenta a Lei oㅡ 8.080, de 1990, para dispor sobre a organização do Sistema Único de Saúde (SUS), o planejamento da saúde, a assistência à saúde e a articulação interfederativa; Considerando a Portaria no 971/GM/MS, de 3 de maio de 2006, que aprova a Política Nacional de Práticas Integrativas e Complementares (PNPIC) no Sistema Único de Saúde. Considerando a Portaria no 2.488/GM/MS, de 21 de outubro de 2011, que aprova a Política Nacional de Atenção Básica, estabelecendo a revisão de diretrizes e normas para a organização da Atenção Básica, para a Estratégia Saúde da Família (ESF) e o Programa de Agentes Comunitários de Saúde (PACS); Considerando a Portaria no 2.446/GM/MS, de 11 de novembro de 2014 que redefine a Política Nacional de Promoção da Saúde (PNPS) que tem como um dos Objetivos específicos: valorizar os saberes populares e tradicionais e as práticas integrativas e complementares; Considerando a Portaria oㅡ 2.761/GM/MS, de 19 de novembro de 2013, que institui a Política Nacional de Educação Popular em Saúde no âmbito do Sistema Único de Saúde (PNEPS-SUS); Considerando que a Organização Mundial da Saúde (OMS) preconiza o reconhecimento e incorporação das Medicinas Tradicionais e Complementares nos sistemas nacionais de saúde, denominadas pelo Ministério da Saúde do Brasil como Práticas Integrativas e Complementares; e Considerando que as diversas categorias profissionais de saúde no país reconhecem as práticas integrativas e complementares como abordagem de cuidado e que Estados, Distrito Federal e Municípios já tem instituídas em sua rede de saúde as práticas a serem incluídas, resolve:

Art. 1ำ Inclui na Política Nacional de Práticas Integrativas e Complementares (PNPIC), instituída pela Portaria no 971/GM/MS, de 3 de maio de 2006, publicada no Diário Oficial da União no 84, de 4 de maio de 2006, Seção 1, pág 20, as seguintes práticas: Arteterapia, Ayurveda, Biodança, Dança Circular, Meditação, Musicoterapia, Naturopatia, Osteopatia, Quiropraxia, Reflexoterapia, Reiki, Shantala, Terapia Comunitária Integrativa e Yoga apresentadas no anexo a esta Portaria.

Art 2ํㅡㄹ Define que as práticas citadas nesta Portaria atendem as diretrizes da Política Nacional de Práticas Integrativas e Complementares no SUS.

Art. 3ํㅡㄹ Esta Portaria entra em vigor na data de sua publicação.

RICARDO BARROS 